Edited by Paul J.J.M. Bakker

With contributions from: Jean-Baptiste Brenet (Universite de Paris I - Pantheon-Sorbonne), Cristina Cerami (cnrs, umr 7219:sphere/chspam), Silvia Donati (Albertus-Magnus-Institut, Bonn), Dag Nikolaus Hasse (Julius-Maximilians-Universitat Wurzburg), Craig Martin (Oakland University), Edith Dudley Sylla (North Carolina State University), Cecilia Trifogli (All Souls College, Oxford)

(C) 2015 by Leuven University Press / Presses Universitaires de Louvain / Universitaire Pers Leuven, Minderbroedersstraat 4, B-3000 Leuven (Belgium)

ISBN 9789462700468

D / 2015 / 1869 / 48

Distributed by Leuven University Press

http://upers.kuleuven.be/nl/book/9789462700468

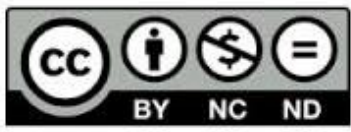

This work is licensed under a Creative Commons Attribution-NonCommercial-NoDerivs 3.0 Unported License: http://creativecommons.org/licenses/by-nc-nd/3.0/ 


\section{AVERROES' NATURAL PHILOSOPHY AND ITS RECEPTION IN THE LATIN WEST}

Edited by

Paul J.J.M. Bakker

LEUVEN UNIVERSITY PRESS 
(C) 2015 by De Wulf-Mansioncentrum - De Wulf-Mansion Centre Leuven University Press / Presses Universitaires de Louvain /

Universitaire Pers Leuven

Minderbroedersstraat 4, B-3000 Leuven (Belgium)

All rights reserved. Except in those cases expressly determined by law, no part of this publication may be multiplied, saved in an automated datafile or made public in any way whatsoever without the express prior written consent of the publishers.

ISBN 9789462700468

$\mathrm{D} / 2015 / 1869 / 48$

NUR: 732

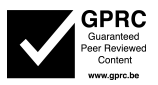




\section{CONTENTS}

PAUL J.J.M. BAKKER,

Introduction

CRISTINA CERAMI,

L'éternel par soi

JEAN-BAPTISTE BRENET,

Alexandre d'Aphrodise ou le matérialiste malgré lui

DAG NIKOLAUS HASSE,

Averroes' Critique of Ptolemy and Its Reception by John of Jandun and Agostino Nifo

SILVIA DONATI,

Is Celestial Motion a Natural Motion?

CECILIA TRIFOGLI,

The Reception of Averroes' View on Motion in the Latin West

EDITH DUDLEY SYLLA,

Averroes and Fourteenth-Century Theories of Alteration

CRAIG MARTIN,

Providence and Seventeenth-Century Attacks on Averroes

Bibliography

Index Codicum Manu Scriptorum

239

Index Nominum

241 


\title{
PROVIDENCE AND SEVENTEENTH-CENTURY ATTACKS ON AVERROES
}

\author{
Craig Martin
}

\section{INTRODUCTION}

Averroes' legacy during the seventeenth century reflected the changing intellectual climate of that century yet was not entirely divorced from earlier disputes and movements. Despite the fact that he was no longer representative of the dominant forms of Aristotelianism, Averroes frequently became a point of reference in attacks on Aristotelianism during the seventeenth century. These attacks pointed at him out of a variety of motivations conditioned by developments within new natural philosophies and reformed theology.

Some thinkers found Averroes to be an emblem of a version of natural philosophy that was more concerned with terminology than nature. The Oratorian advocate of Cartesian philosophy Bernard Lamy, for example, believed that Aristotle's thought had been contorted so that it was unrecognizable and unintelligible. The blame lay on Averroes. Thus in 1683 he wrote, 'Today we understand this Philosopher [Aristotle] in another manner. It is not at all his philosophy that reigns in the schools, it is that of the Arabs.' ${ }^{2}$ Of these 'Arabs,' according to Lamy, 'Averroes is the most weighty.'3 According to Lamy, 'the philosophy of the Arabs is merely a form of questioning that applies the prejudices of childhood to the terminology of Aristotle."

While his attribution of Averroism to French university teachings of the time might be doubted, his attacks on Aristotelianism were characteristic. A number of opponents of traditional university teachings attempted to profit from negative asso-

\footnotetext{
${ }^{1}$ Some of the material of this article is treated in an expanded form in C. Martin, Subverting Aristotle: Religion, History, and Philosophy in Early Modern Science, Baltimore: Johns Hopkins University, 2014.

${ }^{2}$ B. Lamy, Entretiens sur les sciences, dans lesquels on apprend comment l'on doit étudier les sciences, et s'en servir pour se faire l'esprit juste, et le coeur droit, ed. F. Girbal \& P. Clair, Paris: Presses Universitaires de France, 1966 (Le mouvement des idées au XVII siècle, 5), 254: 'Aujourd' huy on entend ce Philosophe d' une autre maniere. Ce n'est point proprement sa Philosophie qui regne dans les Ecoles, c' est celle des Arabes.'

${ }^{3}$ Lamy, Entretiens, 236: 'Aprés eux étoient rangés les Commentateurs Arabes, entre lesquels Averroës est le plus considerable'

${ }^{4}$ Lamy, Entretiens, 255: 'Pour entendre la Philosophie des Arabes, il n'est question que d'apliquer aux termes d'Aristote, les préventions de l'Enfance.'
} 
ciations of Averroes. Johannes De Raei, who combined Cartesian and Aristotelian natural philosophy, prefaced his Clavis philosophiae naturalis (1654) with a diatribe in which he concluded Averroes possessed 'an incredible impiety and most dense ignorance of divine matters. ${ }^{5}$ Other seventeenth-century scholars, such as Pierre Gassendi and Adrianus Heereboord, found Averroes, because of his adherence to what he considered a literal reading of Aristotle, to be a useful frame of reference in promoting the libertas philosophandi (liberty of philosophizing), a concept and trope that held that some universities and other conservative institutions excluded all alternatives to Aristotelianism and as a result eliminated freedom of thought and access to the truth. ${ }^{6}$

These seventeenth-century attacks that linked Aristotelianism to Averroes were in some sense artifacts of a bygone age. While Aristotelianism was still prominent in universities and Jesuit colleges in France, the Netherlands, Italy, and elsewhere, the accepted version of Aristotelianism was not closely aligned to Averroes. Jesuits, for example, carefully deemphasized his views, eliminating them from their lectures and commentaries. The 1591 and 1599 Rationes studiorum, which gave guidelines for Jesuit teachings, directed instructors to avoid praising Averroes in cases where he wrote something good. Each of his errors, to the contrary, should be used as a means to lessen his authority. ${ }^{7}$ Reliance on Averroes' commentaries diminished even in Italian universities, his traditional stronghold, by the end of the sixteenth century. ${ }^{8}$ After being printed in Italy over ten times beginning in the 1470s, Averroes' collected works were never published again after $1576 .^{9}$

Averroes' flagging influence is reflected in Theophile Raynaud's judgment. In his 1653 work De malis ac bonis libris, the Jesuit wrote, 'Now Averroes, having been

${ }^{5}$ J. De Raei, Clavis philosophiae naturalis seu Introductio ad naturae contemplationem Aristotelico-Cartesiana, Leiden: J. \& D. Elzevier, 1654, sig. " $3^{\mathrm{r}}$ : 'Ut enim iam non dicam de incredibili hominis impietate \& crassissima rerum divinarum ignorantia.' For De Raei's hostility to Averroes, see M. Grene, 'Aristotelico-Cartesian Themes in Natural Philosophy: Some Seventeenth-Century Cases', Perspectives on Science, 1 (1993), 66-87, at 72-75.

${ }^{6}$ A. Heereboord, Meletemata philosophica, Nijmegen: A. Hoogenhuysen, 1665, 330; P. Gassendi, Opuscula philosophica, Lyon: L. Anisson \& J.B. Devenet, 1658, 111.

${ }^{7}$ L. Lukács (ed.), Monumenta paedagogica Societatis Iesu, 5: Ratio atque institutio studiorum Societatis Iesu (1586, 1591, 1599), nova editio penitus retracta, Roma: Institutum Historicum Societatis Jesu, 1986 (Monumenta historica Societatis Iesu, 129), 283.

${ }^{8}$ B. Nardi, 'La fine dell'averroismo', in: Id., Saggi sull'aristotelismo padovano dal secolo XIV al XV, Firenze: Sansoni, 1958 (Studi sulla tradizione Aristotelica nel Veneto, 1), 443-455.

${ }^{9}$ M. Campanini, 'Edizioni e traduzioni di Averroè tra XIV e xvi secolo', in: J. Hamesse \& M. Fattori (eds), Lexiques et glossaires philosophiques de la Renaissance, Louvain-la-Neuve: Fédération Internationale des Instituts d'Etudes Médiévales, 2004 (Textes et études du Moyen Age, 23), 21-42. 
tossed from a bridge, has left the schools. ${ }^{10}$ In his opinion, Machiavelli, Cardano, Pomponazzi, and proponents of magic had replaced the threat that Averroes once posed. Less than thirty years later, Gottfried Wilhelm Leibniz agreed with Raynaud and wrote in the perfect tense about 'Averroists' who 'once' believed in the theory of double truth, thereby suggesting that they no longer populated lecture halls. ${ }^{11}$ Writing in the 1690 s, Pierre Bayle supported these assessments. Noting that Ramon Llull had tried without success to have Averroes' commentaries condemned in the fourteenth century, Bayle wrote that there was no longer a need to proscribe his works because, 'his authority is non-existent, and no one wastes the time to read him. ${ }^{12}$ By the end of the seventeenth century, Averroes might have been irrelevant, yet he still remained etched in the collective imagination.

The real target of seventeenth-century attacks on Averroes was the Aristotelians that held sway in the universities, such as Francisco Suárez, Francisco Toletus, and the Coimbrans in Catholic universities and colleges, or Gisbertus Voetius in the Netherlands. ${ }^{13}$ The piety of their philosophical doctrines, often tied to Thomistic interpretations of Aristotle, however, could not be questioned directly, even if the innovators in natural philosophy were religiously motivated. Rather the rhetorical strategy for anti-Aristotelians included associating the bans of teaching other philosophies with the alleged slavishness and impiety of Averroes. Averroes, a Muslim, long known for unorthodox doctrine and seen by humanists as the epitome of barbarous, poorly translated language, of the improper use of philosophy, and of disregard for Christianity, was ideal for casting doubt on Aristotle's own piety.

Attacks on Averroes during the late sixteenth century and seventeenth century, at least partially, shifted away from concerns about his psychology. In Italian universities after the middle of the sixteenth century, Averroes' position on the intellective

${ }^{10}$ T. Raynaud, Erotemata de malis ac bonis libris, Lyon: J.A. Huguetan \& M.A. Ravaud, 1653, 200: 'Nunc Averroes in scholis depontanus evasit'.

${ }^{11}$ G.W. Leibniz, Sämtliche Schriften und Briefe, 6. Reihe: Philosophische Schriften, Berlin: Akademie-Verlag, 1923-, 6/4a: 464.

${ }^{12}$ P. Bayle, Dictionnaire historique et critique, $5^{\text {th }}$ ed., 4 vols, Amsterdam: P. Brunel, 1740, 1: 387 , n. 51: 'Son autorité est nulle, \& personne ne perd du tems à le lire.'

${ }^{13}$ For Voetius' combining of theology and Aristotelian philosophy see Th. Verbeek, Descartes and the Dutch: Early Reactions to Cartesian Philosophy, 1637-165o, Carbondale (IL): Southern Illinois University Press, 1992, 7, and A.J. Beck, Gisbertus Voetius (1589-1676): sein Theologieverständnis und seine Gotteslehre, Göttingen: Vandenhoeck \& Ruprecht, 2007 (Forschungen zur Kirchen- und Dogmengeschichte, 92). For the character of late scholasticism see D. Des Chene, Physiologia: Natural Philosophy in Late Aristotelian and Cartesian Thought, Ithaca (NY): Cornell University Press, 1996. 
soul was no longer philosophically attractive. ${ }^{14}$ René Descartes illustrates these diminishing concerns over the unicity thesis. In the preface to the Meditations (1641), Descartes cited the Fifth Lateran Council and its assertions about the primacy of the Church's teachings of the soul as expressed at the Council of Vienne. Yet Descartes did not mention the passage that referred to the condemnation of the view that the soul is 'unica in cunctis hominibus' but only referred to the Council's concerns with materialist and mortalist positions regarding the soul. ${ }^{15}$ While Descartes' concerns with materialist psychology might have been defensive - reflecting the possibility that he might be accused of proposing a mortal soul but not a single passive intellect for all humans - they also show that the philosophical attraction of Averroes' views on the soul had failed to register as a possible solution even though it had enticed many thinkers a century earlier.

The issue that emerged in seventeenth-century attacks on Averroes surrounded God's providence in the sublunary realm. The issue of providence in natural philosophy grew in importance during the sixteenth century. The roots of this growing emphasis are found in Philipp Melanchthon's reformulation of Aristotelian natural philosophy, which attempted to make the concept of providence a foundation for investigations into nature. ${ }^{16}$ Accordingly, for Lutheran natural philosophers providence played a significant role in explanations of a variety of natural phenomena,

\footnotetext{
${ }^{14}$ See D.N. Hasse, 'Aufstieg und Niedergang des Averroismus in der Renaissance: Niccolò Tignosi, Agostino, Nifo, Francesco Vimercato,' in: J.A. Aertsen \& M. Pickavé (eds), Herbst des Mittelalters? Fragen zur Berwertung des 14. und 15. Jahrhunderts, Berlin [etc.]: De Gruyter, 2004 (Miscellanea Mediaevalia, 31), 447-473, and Id., 'The Attraction of Averroism in the Renaissance: Vernia, Achillini, Prassicio', in: P. Adamson, H. Baltussen \& M.W.F. Stone (eds), Philosophy, Science and Exegesis in Greek, Arabic and Latin Commentaries, London: Institute of Classical Studies, 2004, 131-147.

${ }^{15}$ Ch. Adam, \& P. Tannery (eds), Euvres de Descartes, Paris: Vrin, 1996, 7: 3. For the text of the Fifth Lateran Council see H. Jedin, Conciliorum oecumenicorum decreta, Bologna: Istituto per le Scienze Religiose, 1973, 605. For various interpretations of the bull that prohibited teaching the mortality or the unicity of the soul, see F. Gilbert, 'Cristianesimo, umanesimo e la bolla Apostolici Regiminis del 1513, Rivista storica italiana, 79 (1967), 976-990, and E.A. Constant, 'A Reinterpretation of the Fifth Lateran Council Decree Apostolici Regiminis (1513), The Sixteenth Century Journal, 33 (2002), 353-379. For the Council of Vienne and its reception, see W. Duba, 'The Souls after Vienne: Franciscan Theologians' Views on the Plurality of Forms and the Plurality of Souls, ca. 1315-1330', in: P.J.J.M. Bakker, S.W. de Boer \& C. Leijenhorst (eds), Psychology and the Other Disciplines: A Case of Cross-Disciplinary Interaction (1250-1750), Leiden [etc.]: Brill, 2012 (Medieval and early modern science, 19), 171-272.

${ }^{16}$ See S. Kusukawa, The Transformation of Natural Philosophy: The Case of Philip Melanchthon, Cambridge: Cambridge University Press, 1995 (Ideas in context, 34).
} 
including the nature of living things, meteorological phenomena, and astronomy. ${ }^{17}$ Calvinist and Catholic theologians and philosophers soon followed similar paths. The revival of atomist philosophies also mandated a careful touch with the issue of providence, because Epicurus had long been associated with the denial of providence and hence impiety. ${ }^{18}$ Lutherans used his name as a synecdoche for this position. ${ }^{19}$ As a result, Pierre Gassendi was forced to demonstrate how his revival of Epicureanism could be reconciled with Christian conceptions of God's power and care. ${ }^{20}$ If atomism was to be revived, a new figure was needed as the symbol of a philosophy without providence. That figure was Averroes.

\section{MEDIEVAL AND EARLY RENAISSANCE ORIGINS}

Associating Averroes with a sublunary world not directly governed by God predates the seventeenth-century revival of Epicurean philosophy. Pirro Ligorio's reaction to the 1570 earthquake in Ferrara perhaps helps illustrate the shifting weight placed on concerns over Averroes' position on providence. At the time of the earthquake, Ligorio was an antiquarian employed at this time in the House of Este's court. Dismissing papal accusations that the cause of the earthquake was divine punishment against the Ferrarese for accepting the Jews, whom Pius $v$ had recently expelled from the Papal States, Ligorio contended there was another cause for these temblors. The divine punishment was not for protecting Jewish refugees, put rather aimed at 'those who are so bold that ... they deny God's providence, having been deceived by Aristotle, Galen, Averroes, Alexander of Aphrodisias, and other Peripatetics. ${ }^{21}$ Thus Averroes was a member of a group of thinkers who denied providence by dismissing the role of divine intervention in the sublunary world. According to

\footnotetext{
${ }^{17}$ See Kusukawa, The Transformation, 75-123; C. Methuen, 'Special Providence and Sixteenth-Century Astronomical Observation: Some Preliminary Observations,' Early Science and Medicine, 4 (1999), 99-113; and C. Martin, 'The Ends of Weather: Teleology in Renaissance Meteorology',Journal of the History of Philosophy, 48 (2010), 259-282.

${ }^{18} \mathrm{H}$. Jones, The Epicurean Tradition, London [etc.]: Routledge, 2001, 95-116.

${ }^{19}$ R.D. Preus, The Theology of Post-Reformation Lutheranism, 2, St. Louis: Concordia Publishing House, 1972, 196.

${ }^{20}$ M.J. Osler, 'Providence and Divine Will in Gassendi's Views on Scientific Knowledge', Journal of the History of Ideas, 44 (1983), 549-56o.

${ }^{21}$ P. Ligorio, Libro di diversi terremoti, ed. E. Guidoboni, Roma: De Luca Editori d'Arte, 2005 (Libri delle antichità, 28), 5: 'sono tanto temerarii che ... negano la Providentia d'Iddio gabbati da Aristotele, da Galeno metafrasta, da Averroi et da Alexandro Aphrodiseo et dagli altri peripatetici.'
} 
Ligorio's scenario, that scholars followed Averroes' view that there was no divine providence in the sublunary sphere angered God to such a degree that in order to demonstrate his control of natural particulars he destroyed Ferrara.

Ligorio's view was not isolated. The complaint that Averroes or Aristotle denied providence has a long history, its origins nearly contemporaneous with the introduction of Averroes' thought into the Latin West in the thirteenth century. Bonaventure traced the doctrine to Aristotle himself, arguing that Aristotle's rejection of Plato's Forms led to a denial of providence because it eliminated God's ability to have knowledge of all things. Unnamed 'Arabs' compounded this error, by maintaining a 'fatal necessity' based on the argument that if there is no providence, then the substances moving the orb must be the cause of everything. ${ }^{22}$ In the Errors of the philosophers (ca. 1270), Giles of Rome listed among these errors Averroes' position that 'God does not have any providence over individuals, ${ }^{, 23}$ presumably in reference to comment 37 of book twelve of the long commentary on Aristotle's Metaphysics. There, after explaining that the celestial bodies, having been moved by the unmoved mover, cause generation and corruption in the sublunary region, Averroes contended that:

This is the source of God's providence for all existents. He knows them by species, since it is not possible to know them numerically. The view of those who think that God's providence extends to every person is right in a sense and wrong in another. It is right insofar as nobody is in a condition peculiar to him, but (this condition) belongs to the class of this species. If this is so, it is correct to say that God takes care of individuals in this way; but providence for an individual, in which nobody else shares, is something that the divine bounty does not necessitate. ${ }^{24}$

Here Averroes contended that God has some concern with individuals because all individuals obtain their disposition from their species, which are connected to God,

\footnotetext{
${ }^{22}$ Bonaventure, Collationes in Hexaëmeron, Ad Claras Aquas (Quarrachi): Collegium S. Bonaventura, 1891 (Opera omnia, 5), 360-361. See E. Gilson, Le Thomisme: Introduction au système de Saint Thomas D’Aquin, Paris: Vrin, 1927 (Etudes de philosophie médiévale, 3), $26-27$.

${ }^{23}$ Giles of Rome, Errores philosophorum, ed. J. Koch, tr. J.O. Riedl, Milwaukee (wI): Marquette University Press, 1944, 25 (nr. 6).

${ }^{24}$ Translation (with slight modification) from Ch. Genequand, Ibn Rushd's Metaphysics: A Translation with Introduction of Ibn Rushd's Commentary on Aristotle's Metaphysics, Book Läm, Leiden [etc.]: Brill, 1984 (Islamic philosophy and theology, 1), 155. For the Latin text, see Averroes, In Metaphysicam, in: Aristotelis opera cum Averrois commentariis, 8, Venezia: Apud Junctas, 1562-1574 (repr. Frankfurt am Main: Minerva, 1962), 320v.
} 
yet God does not directly communicate with sublunary individuals. This passage became the source for the widely held view that Averroes did not believe there was providence in the sublunary world.

Thomas Aquinas quoted this passage in his commentary on the first book of Peter Lombard's Sentences, where he discussed whether there is providence for everything. Thomas divided those who denied providence into two camps, those, like Democritus, who deny all providence, and those, namely Averroes, who admit providence with regard to species but deny that particulars are governed as such. Thomas was careful to distinguish between Averroes' position and Aristotle's, maintaining that despite Averroes' attribution of this view to Aristotle, Aristotle did not in fact hold this position. Moreover, according to Thomas, Averroes' position was not in accordance with Christian belief because it 'removes God's judgment from the works of humankind. ${ }^{25}$ Thus Thomas believed Averroes erred twice. He misinterpreted Aristotle and was incorrect about the nature of providence.

Thomas' views informed Renaissance debates. During the middle of the fifteenth century, controversies over the relative merits of Aristotle and Plato erupted among Greek emigrants to Italy. Georgios Gemistos Plethon praised Plato and dismissed Aristotle, and more particularly Aristotelians 'convinced by the claims of the Arab Averroes. ${ }^{26}$ Implicitly suggesting that Averroes' interpretation was correct, Plethon pointed to one of Aristotle's failings being his view that 'God [is] the end not of the existence or essence of particular things but only of movement and change', in general. ${ }^{27}$ George Trapezuntius countered and contended, following Thomas Aquinas, that Aristotle believed that God's providence extended to sublunary individuals. Cardinal Bessarion, in turn, opposed Trapezuntius in his In calumniatorem Platonis, a work that responded, at times viciously, to Trapezuntius' attack on Plethon. Bessarion's defense of Plato took the position that Averroes correctly interpreted Aristotle's view. Aristotle's view, however, was incorrect and its impiety allegedly shows the difficulty of reconciling Aristotle with Christianity and the superiority of Plato over Aristotle. ${ }^{28}$

${ }^{25}$ Thomas Aquinas, Scriptum super primum librum Sententiarum, d. 39, q. 2, a. 2, ed. P. Mandonnet, Paris: Lethellieux, 1929, 931: 'Sed haec opinio expresse tollit judicium Dei de operibus hominum.'

${ }^{26}$ Plethon, De differentiis, 1. For the Greek text, see B. Lagarde, 'Le De differentiis de Pléthon d'après l'autographe de la marcienne', Byzantion, 43 (1973), 312-343. Translation from C.M. Woodhouse, George Gemistos Plethon: The Last of the Hellenes, Oxford: Clarendon Press, 1986, 192.

${ }^{27}$ Plethon, De differentiis, 3. Translation from Woodhouse, George Gemistos Plethon, 192.

${ }^{28} \mathrm{~J}$. Bessarion, In calumniatorem Platonis libri IV, ed. L. Mohler, Paderborn: Schöningh, $1927,414-415$ (III, 29, 1). 
What emerged from the Plato-Aristotle debates was a dual question. The first was philosophical or theological - whether God's providence extends to particulars. The second was historical or interpretative. Did Averroes correctly interpret Aristotle? Did Aristotle hold that God's providence was limited to the celestial realms? While there are exceptions, the schema that emerged was perhaps unlikely. The Platonists, Plethon and Bessarion, sided with Averroes over Thomas, believing that Aristotle did hold this position, while the Aristotelian Trapezuntius was dismissive of Averroes. This pattern continued, with some exceptions.

One such exception was the Platonist Marsilio Ficino, who attacked Averroes' views about providence as well as his interpretation of Aristotle. Associating him with Epicurus, Ficino called Averroes impious because of his lack of awareness that Aristotle 'claims that individual parts are led back to the good of the order which is in the whole as to their end. ${ }^{29}$ While it is unclear how this view undermines Averroes' view of providence, it is evidence that Ficino believed Averroes misinterpreted Aristotle. Ficino, like many other humanists, made the interpretation of texts central to his attack on Averroes. Arguing that Averroes' faults were due to textual and linguistic issues, from his reading books that had been 'perverted rather than converted ... into a barbarous tongue,' Ficino wrote that the 'words of Aristotle in Greek contradict Averroes. ${ }^{30}$ Averroes' ignorance of Greek undermined his ability to interpret ancient texts and thus his authority.

Ficino found an ally in Pietro Pomponazzi for his view that Aristotle believed in providence in the sublunary realm. Despite Pomponazzi's reputation for impiety, he concluded that the view that divine providence extends only to celestial bodies and intelligences is 'false and incorrectly attributed to Aristotle. ${ }^{31}$ This interpretation of Aristotle, according to Pomponazzi, derives from Calcidius. ${ }^{32}$ Calcidius' interpretation of Aristotle, however, is not in agreement with Averroes, who 'most openly puts forward a God that is concerned with inferior matters. ${ }^{33}$ Thus he

\footnotetext{
${ }^{29}$ M. Ficino, Platonic Theology, tr. M.J.B. Allen \& ed. J. Hankins, 1, Cambridge (MA): Harvard University Press, 2001, 155 (2.97). Cf. Aristotle, Metaphysics, XII.10, $1075 a 10$.

${ }^{30}$ M. Ficino, Platonic Theology, tr. M.J.B. Allen \& ed. J. Hankins, 5, Cambridge (MA): Harvard University Press, 2005, 9 (15.1.2).

${ }^{31}$ P. Pomponazzi, Libri quinque de fato, de libero arbitrio et de praedestinatione, ed. R. Lemay, Lucani: Thesaurus mundi, 1957 (Thesaurus mundi, 8), 166: 'Haec autem positio proculdubio sic intellecta ut verba sonant, et in se est falsa, et perperam Aristoteli ascribitur'.

${ }^{32}$ Calcidius, Timaeus a Calcidio translatus commentarioque instructus, Editio altera, ed. J.H. Waszink, Leiden [etc.]: Brill, 1975 (Plato latinus, 4), 250.

${ }^{33}$ Pomponazzi, De fato 165: 'Apertissime ponit Deum sollicitari circa haec inferiora ut suo modo convenit.' Pomponazzi cited comments 18, 36, 41, 51, 52 of book XII of the long
} 
disagreed with Ficino's assessment of Averroes, and hence Thomas', Bessarion's, and Plethon's, while agreeing with their views of providence.

\section{LATE-RENAISSANCE THEOLOGY, PHILOSOPHY, AND PHILOLOGY}

Ficino's and Pomponazzi's views persuaded some, such as Lucillo Filalteo, who contended that while Aristotle admitted providence, the 'Barbarous Averroes' denied it out of impiety. ${ }^{34}$ Nevertheless investigations into the history of philosophy - and theology - continued during the sixteenth century. A revived interest in the Church Father's views of Greek philosophy undermined attempts to reconcile Aristotle with certain Christian doctrines. In the 1550s, Guillaume Postel, a man himself accused of impiety by both Calvinists and Catholics, brought forth the teachings of Justin Martyr in an effort to discredit Aristotle's followers, or in his words 'in order to overturn the authority of Aristotle, where it is contrary either to divine authority or reason. ${ }^{35}$ According to Postel, his work (and Justin Martyr's as well) was needed because since antiquity 'cohorts of atheists' have used Aristotle's ambiguity to prove that there is no providence in particulars. ${ }^{36}$ One member of this group was Averroes, whom Postel described as 'the greatest enemy of providence. ${ }^{37}$ Postel believed developers of scholastic doctrine, the school at Paris, and sacred authorities 'strip these [divine] truths from Aristotle' while 'he himself lies completely neglected. ${ }^{38}$

commentary on Aristotle's Metaphysics as places where Averroes asserts providence extends to sublunary particulars.

${ }^{34}$ L. Filalteo, In IIII. libros Aristotelis De caelo et mundo commentarii, Venezia: Vincentius Valgrisius, 1565, 418: 'Barbarus Averroes eo impietatis venit ut negaret Divinam providentiam.

${ }^{35}$ G. Postel, Eversio falsorum Aristotelis dogmatum, Paris: Sebastianus Nivellius, $1552,75^{\mathrm{r}-\mathrm{v}}$ : 'Licet ipse sanctus Martyr cuius iam totis mille \& quadringentis circiter annis scripta Graeca extant, possit abunde sibi satis esse \& in evertenda Aristotelis authoritate, ubi aut divinae authoritati aut rationi contraria est.' For Postel's uneasy relations with both Calvinists and the Inquisition, see W.J. Bouwsma, Concordia Mundi: The Career and Thought of Guillaume Postel (1510-1581), Cambridge (MA): Harvard University Press, 1957 (Harvard Historical monographs, 33), $1-29$.

${ }^{36}$ Postel, Eversio, $4^{\mathrm{r}}$.

${ }^{37}$ G. Postel, Liber de causis, Paris: Sébastien Nivelle, 1552, sig. B 1: 'Quum autem vocarit Aben Reis (cuius libentius sententiam meae confirmatoriam tanquam a summo providentiae hoste \& recipio \& maxime ob Ismaelem, Abrahamicique Sanguinis nomen \& jura, quam Aristotelis) ...

${ }^{38}$ Postel, Eversio, 81 ${ }^{\mathrm{v}}$ : 'Ipsa schola Parisiensi aut doctrina scholastica, tota (quatenus ecclesiae fuit in hanc diem cognitu necessaria \& intelligibilis) sacrorum authoritas innumeris rationibus in utramque partem discussa, spoliaret Aristotelem illis veritatibus, quae in ipso 
In his eyes, scholastics ignore the real historical Aristotle, distorting his writings and siding with Averroes.

Postel's unorthodoxy made him unattractive for many. But his attempt to use the Church fathers to undermine the Catholic Church's appropriation of Aristotle corresponded to others' attacks on Averroes' views of providence. For example, Jacopo Mazzoni, in his 1576 comparison of Plato and Aristotle, after arguing that Plato's thought conformed to Catholicism based on the authority of Church fathers, concluded that Plato's views on providence agree with Scripture, while Averroes' belief that matter is uncreated leads to potential ambiguities on the subject. ${ }^{39}$ In a similar vein Francesco De' Vieri (1547-159o), a professor at Pisa, noted that Plato's doctrines were well received by the 'Greek Doctors' of the Church. ${ }^{40}$ Among Plato's doctrines that De' Vieri believed conformed to Christianity, but not to Aristotle's thought, was that 'God has providence over all things, in particular over man.41 Related doctrines, allegedly both Platonic and Christian, included that God answers prayers, God uses angels to take care of humans, and God protects the weak and punishes the proud. ${ }^{42}$ While De' Vieri believed that at times Plato and Aristotle agreed with each other and with true religion, other Platonists, such as Francesco Patrizi, were far more hostile to Aristotle and his followers.

In his habitually exhaustive manner, Patrizi cited a number of patristic sources, not just Justin Martyr, in his discussion of Aristotle's doctrinal missteps in the 1591 Nova de universis philosophia. This work was an attempt, not unlike Bessarion's or Plethon's of the previous century, to show that Platonic philosophy corresponded better to Catholic theology than Aristotelian thought did. In the preface to the 'future' Pope Gregory XIV, he began with the rhetorical question: 'Why are only those parts of Aristotle's philosophy read, which are most injurious to God and the Church? ${ }^{43}$ Contending that for the last 400 years 'scholastic theologians' have used 'Aristotelian impieties for the foundations of faith', he listed Dionysius the

liquidae erant, eo quod veritas a quocunque dicatur a spiritu sancto est, \& semper divina: ut tandem post resolutiones ipsas sacrorum, ipse Aristoteles omnino neglectus iaceret.'

${ }^{39}$ J. Mazzoni, In universam Platonis et Aristotelis philosophiam praeludia, sive de comparatione Platonis et Aristotelis, ed. S. Matteoli, Napoli: M. D’Auria, 2010 (Storie e testi, 19), 311-325.

${ }^{40}$ F. De' Vieri, Vere conclusioni di Platone conformi alla Dottrina Christiana et a quella d'Aristotile, Firenze: Georgio Marescotti, 1590, 3.

${ }^{41}$ De' Vieri, Vere conclusioni, 12: 'Dio ha providenza di tutte le cose, \& in particolare dell'huomo.'

${ }^{42}$ De' Vieri, Vere conclusioni, 13-14.

${ }^{43}$ F. Patrizi, Nova de universis philosophia, Ferrara: Benedictus Mammarellus, 1591, sig. a $3^{\mathrm{r}}$ : 'Cur Aristotelis philosophiae, solae eae praeleguntur partes, quae magis \& Deo, \& Ecclesiae suae sunt hostes?' 
Areopagite, Justin Martyr, Clement of Alexandria, Arnobius, Lactantius, Cyril, Basil, Eusebius, Theodoretus, Augustine, and Ambrosius as proponents of Platonism and opponents of Aristotle. ${ }^{44}$

One of the doctrines Patrizi found most problematic was the absence of providence in the sublunary realm. According to Patrizi, Origen wrote, 'Aristotle was worse than Epicurus, because he was impious in divine providence. ${ }^{45}$ Clement of Alexandria complained that for Aristotle 'providence extended only to the moon. ${ }^{46}$ Accordingly, Patrizi placed the Church fathers in agreement with Averroes' interpretation that Aristotle limited providence, yet he disagreed with the Aristotelian position. Those in 'the Parisian school', he wrote, 'explained the universe, imitating Averroes' commentaries', thereby mixing 'the most sordid' into the Catholic faith. ${ }^{47}$ For Patrizi, the alternative was Plato's thought, which he believed corresponded to Christian theology much better. Ecclesiastical authorities had other ideas, bringing Patrizi to the Inquisition, leading him to revise his writings. ${ }^{48}$

While Patrizi was extreme in his Platonism, his views of Aristotle resonated with those of the most famous Aristotelians of the day. Although some have seen the disclaimers of Pietro Pomponazzi and Cesare Cremonini that they were not writing the truth but rather interpreting Aristotle as ruses to mask their own views, nevertheless, their adherence to Averroes' position need not mark their impiety but rather what they saw as their fidelity to accurate textual interpretation. In the case of the question of sublunary providence, Bessarion's view that Thomas was wrong to assert that Averroes misinterpreted Aristotle was shared not just by Patrizi and De' Vieri, but by Aristotelians as well. Patrizi was friends with Cremonini, both had spent time in Ferrara, and Patrizi even dedicated his Apologia contra

\footnotetext{
${ }^{44}$ Patrizi, Nova de universis philosophia, sig. a ${ }^{\mathrm{r}}$ : 'Quadringentis vero ab hinc circiter annis, Scholasticis Theologi, in contrarium sunt annixi, Aristotelicis impietatibus, pro fidei fundamentis sunt usi.'

${ }^{45}$ Patrizi, Nova de universis philosophia, 49v: 'Origines quoque Aristotelem Epicuro inferiorem dicit esse, quia fuerit in divinam providentiam impius.'

${ }^{46}$ Patrizi, Nova de universis philosophia, 49": 'Clemens quoque Alexandrinus Origenis praeceptor, Aristotelem, \& Peripateticos incusat ... providentiamque usque ad lunam tantum porrigi.'

${ }^{47}$ Patrizi, Nova de universis philosophia, 49v: 'Qui e Parisiana schola ... nec solum, in eius philosophiam, magnis laboribus incubuerunt, sed vel partem, vel etiam universam Aven Rois imitati, commentariis, quamvis satis infeliciter, explanarunt. Sed etiam ipsum, invitum, \& maxime omnium repugnantem, \& contradictem, Christianum effecerunt.'

${ }^{48}$ For how Patrizi changed the Nova de universis philosophia as a result of the Inquisition, see F. Patrizi, Nova de universis philosophia: Materiali per un'edizione emendata, ed. A.L. Puliafito Bleuel, Firenze: Olschki, 1993.
} 
calumnias Theodori Angelutii to him. ${ }^{49}$ Their distant philosophical poles made them unlikely companions, even though their approaches to Aristotle are similar. Both wished to understand the true thought of Aristotle, rather than incorporate it into theology. Patrizi thought such reconciliation was impossible for Aristotle and listed 43 separate points where Aristotle disagreed with the Christian religion. Likewise Cremonini considered Aristotle's philosophy to be separate from theology, and in a sense separate from the truth.

In his Apologia dictorum Aristotelis de quinta caeli substantia (1616), Cremonini described his method as suppositional. While admitting that his arguments might be repugnant to the Christian faith, they were proven from Aristotle's principles. To illustrate his point, he wrote that it is possible to make a Democritean demonstration, explaining effects based on the principles of atoms and void. Such a demonstration, however, will be false, according to Cremonini. The same is true for Aristotle. Using Aristotelian principles it is possible to make demonstrations that are valid according to the initial suppositions, but not necessarily true. Cremonini wrote, 'I do not say that he simply reached the truth, since he erred when he opines against the faith., ${ }^{50}$ For some, Cremonini's approach suggests masked impiety or insincerity, but it need not. ${ }^{51}$ Bessarion and Patrizi have not received the same accusations for arguing Aristotle is incompatible with faith.

In any case, Cremonini applied this suppositional method to the question of providence. He wrote that Aristotle had 'fallen into error, since it is stated by faith and by the decrees of holy theology that God's providence is administered rightly and truly over all singulars. ${ }^{52}$ Yet Averroes was in a sense correct, not dogmatically, but as an interpreter of Aristotle. Averroes had rendered the doctrine according to 'good Aristotelian sense', although scarcely according to the truth. Yet as an interpretation

\footnotetext{
${ }^{49}$ F. Patrizi, Apologia contra calumnias Theodori Angelutii, Ferrara: Dominicus Mamarellus, 1584 , sig. $\mathrm{A}^{\mathrm{r}}$.

${ }^{50}$ C. Cremonini, Apologia dictorum Aristotelis de quinta caeli substantia adversus Xenarcum, Ioannem Grammaticum, E alios, Venezia: Meietti, 1616, 4-5: 'Sic est etiam de Aristotele, quem non dico simpliciter veritatem attigisse, quippe qui erravit quandocumque contra fidem sensit.'

${ }^{51}$ For a discussion of the various ways Cremonini has been interpreted see H.C. Kuhn, 'Cesare Cremonini: Volti e maschere di un filosofo scomodo per tre secoli e mezzo' in: E. Riondato \& A. Poppi (eds), Cesare Cremonini: Aspetti del pensiero e scritti, Padova: Accademia galileiana di scienze, lettere ed arti in Padova, 2000 (Historia, 1), 153-168.

${ }^{52}$ Cremonini, Apologia, 78: 'Quinimo magnopere in errorem lapsus, ut constat ex fide, \& ex decretis sacrae Theologiae, quibus omnia, \& singula Dei providentia administrari recte \& vere statuitur. \& Averroes: ad bonum sensum nempe Aristotelicum reducendum proponimus, secundum veritatem minime, \& secundum eam, quam profitetur, interpretis Aristotelici doctrinam.'
} 
it makes good sense because Aristotle 'was ignorant of true religion' and its rewards, believing that philosophy itself was its own prize. ${ }^{53}$ Cremonini's approach was similar to that of his predecessors at Padua and Bologna. For example, Alessandro Achillini, a professor at Bologna, wrote in his De distinctionibus (1510) that Aristotle and Averroes did not believe that God was concerned with the properties of individuals that result from chance. According to Achillini, 'this error is quite far from the truth of faith; but in natural philosophy it does not appear to be an error. ${ }^{254}$ During Cremonini's lifetime, Francesco Piccolomini (1520-1604), a professor of philosophy at Padua, argued that for Aristotle, providence derives from the necessity of nature and God's goodness stems from his being a mover of the world, rather than from an 'influence distinct from him. ${ }^{, 55}$ Aristotle's view, however, is the result 'only of proceeding through the works of nature (physica opera), which is not in agreement with the exact truth, which our theologians explain most broadly.56

\section{EARLY MODERN POLEMICS}

Cremonini's and Piccolomini's assessment of Aristotle was shared by a number of writers, often by those who were unsympathetic to Aristotelianism. The promoter of a novel natural philosophy based on the actions of the qualities hot and cold, Bernardino Telesio (1509-1588), argued that Aristotle's philosophy was contrary to Scripture because of the absence of his acknowledging God's 'knowledge and administration of human affairs. ${ }^{57}$ A 1585 treatise that promoted the chymical philosophy attributed to Richard Bostocke complained about Aristotle's 'heathenish

\footnotetext{
${ }^{53}$ Cremonini, Apologia, 79: 'Aristoteles quidem, votum solvendum iudicavit, putans actionem studiosam sibi ipsi esse praemium, quippe. qui ut ignoravit verae religionis cultum, ita nescivit operibus ex vera religione esse aliud praemium aeternum.'

${ }^{54}$ A. Achillini, Opera omnia, Venezia: Hieronymus Scotus, 1568, 312: '\& sic error Aristotelis a veritate fidei parum distat. sed in philosophia naturali non apparet error.'

${ }^{55}$ F. Piccolomini, Librorum ad scientiam de natura attinentium pars secunda, Venezia: De Franciscis, 160o, 41 ${ }^{\mathrm{r}}$ : 'Quae Providentia sequitur eminentissimam Dei cognitionem, qua noscens Deus se ut bonum, vult omne, quod est bonum, \& sua facultate movendo Coelum, motu totius effundit munera bona in universum orbem, idque facit per motum, non per influxum aliquem ab eo distinctum.'

${ }^{56}$ Piccolomini, Librorum ad scientiam de natura attinentium, 41": 'Hanc itaque puto ego de Providentia fuisse opnionem Aristotelis, qui solum per Physica opera progrediens, exactam veritatem inspicere non valuit, quam cum latissime explicent nostri Theologi.'

${ }^{57}$ B. Telesio, De rerum natura iuxta propria principia, ed. L. de Franco, 2 vols, Cosenza: Casa del Libro, 1965, 1: 20: 'et rerum humanarum administrationem cognitionemque Deo demit omnem?
} 
Philosophie' that 'teacheth that God medleth not under the Moone. ${ }^{58}$ In his view, Aristotelian philosophy, following Averroes, 'doth not admit any Metaphisicall principle in naturall thinges,' which makes men forget God and become atheists. ${ }^{59}$ Sebastian Basso, who wished to reform natural philosophy by basing it on Presocratic principles, wrote in 1621 that on the question of providence, sacred writings, all the doctors of the Church, and all the Presocratics were opposed to 'the Averroists and Aristotle himself. ${ }^{\prime 6}$

Authors from both sides of the confessional divide who wrote on heresy and impiety addressed Averroes' views on providence. Philippe de Mornay (Du Plessis) (1549-1623), a French protestant with Platonist leanings, wrote in his 1605 book De veritate religionis that Aristotle's and Averroes' emphasis on nature was impious. ${ }^{61}$ Melchior Cano, a Spanish Dominican, wrote in his De locis theologicis (1563) that the attention given to Aristotle and Averroes in Italy gave birth to the 'pestiferous dogma' about 'divine improvidence around human affairs. ${ }^{\text {'62 }}$ Having cited Cano and a number of Church fathers, Tommaso Campanella enumerated errors of Aristotle in his De gentilismo non retinendo (1636). The second error listed - after the eternity of the world - was that God does not provide for sublunary things. ${ }^{63}$ Campanella also believed that Averroes understood Aristotle better than Albert the Great and Thomas did, because they tried to alter Aristotle in places where he was clearly against the Catholic faith. ${ }^{64}$

These attacks that struck at Aristotle and Thomas' interpretation of him were met by those who wished to maintain the Thomistic synthesis adopted by Jesuits after the Council of Trent. In a point by point refutation of Cano, the Jesuit Antonio

\footnotetext{
${ }^{58}$ R.B. [Richard Bostocke], Auncient Phisicke, London: Walley, 1585, sig. ***\%r

${ }^{59}$ Bostocke, Auncient Phisicke, $7^{\mathrm{r}}$.

${ }^{60}$ S. Basso, Philosophiae naturalis adversus Aristotelem libri xii, Genève: Petrus de la Rouière, 1621, 221: 'Hactenus de secunda quaestione, in qua, sacra Scriptura revelante, concordantibus universis Ecclesiae doctoribus, summo Veterum omnium consensu, adversus Averroistas, ipsumque Aristotelem.'

${ }^{61} \mathrm{Ph}$. de Mornay (Du Plessis), De veritate religionis Christianae, adversus atheos, Epicureos, ethnicos, Iudaeos, Mahumedistas, E caeteros infideles, Leiden: Andries Clouck, 1605, 378.

${ }^{62}$ M. Cano, De locis theologicis libri XII, Salamanca: Mathias Gastius, 1563, 312: 'Audivimus enim Italos esse quosdam, qui suis \& Aristoteli \& Averroi tantum temporis dant, quantum sacris litteris ii, qui maxime sacra doctrina delectantur; tantum vero fidei, quantum Apostolis \& Evangelistis ii, qui maxime sunt in Christi doctrinam religiosi. Ex quo nata sunt in Italia pestifera illa dogmata de mortalitate animi, \& divina circa res humanas improvidentia, si verum est, quod dicitur.'

${ }^{63}$ T. Campanella, De gentilismo non retinendo, Paris: Dubray, 1636, 22

${ }^{64}$ Campanella, De gentilismo, 7-8.
} 
Possevino (1534-1611) cited book $\mathrm{x}$ of the Nicomachean Ethics (1179a24-25) as evidence that Aristotle believed that Gods have some concern over human affairs. ${ }^{65}$ Francisco Toletus (1532-1596) maintained that the Averroists had misinterpreted Aristotle on this question, ${ }^{66}$ although his fellow Jesuit, Pedro da Fonseca (15281599) thought Aristotle's explanations of providence were inadequate. ${ }^{67}$ The Jesuit Antoine Sirmond (1591-1643) made the question of the immortality of the soul depend on the question of God's providence, arguing that any God that provided over human affairs would necessarily also provide for the afterlife. ${ }^{68}$ Jean de Silhon (1596-1667) held a similar view and maintained in his 1626 Les deux vérités that God's goodness requires that the human soul be immortal. ${ }^{69}$ Mersenne's Questions on Genesis (1623) affirmed Thomas' views on providence and linked Averroes' view on providence not to Aristotle but to Cardano and impiety in general. Although a year later in his La vérité des sciences he wrote that De mundo, which he admitted to not knowing if Aristotle had truly written it, "had almost prevented him from believing that Aristotle had denied that God's providence extend to the smallest things. ${ }^{70}$

Lutherans also attacked Aristotelians who limited providence in an effort to promote a version of Aristotelianism that was in concord with Christianity. The Lutheran physician and polemicist Nikolaus Taurellus (1547-1606) wrote a diatribe against Andrea Cesalpino (1519-1603) in which he maintained that Cesalpino's view that God was a speculative intelligence rather than an active one was obscure, barbarous, impious, in error, and uninformed by the meaning of the Greek text. For Taurellus, God's concern over the quotidian was proved by Scripture; and, moreover

\footnotetext{
${ }^{65}$ A. Possevino, Bibliotheca selecta de ratione studiorum in Historia, in Disciplinis, in salute omnium procuranda, 2 vols, Roma: Domenico Basa, 1593, 2: 92.

${ }^{66}$ F. Toletus, Commentaria una cum quaestionibus in octo libros Aristotelis De physica auscultatione, Venezia: Apud Junctas, 1580, 61 ${ }^{\mathrm{r}}, 242^{\mathrm{v}}$.

${ }^{67}$ P. da Fonseca, Commentaria in libros Metaphysicorum Aristotelis Stagiritae, 2 vols, Lyon: Giunta, 1597, 1: 22.

${ }^{68}$ A. Sirmond, De immortalitate animae demonstratio physica E Aristotelica, Paris: Michel Soly, $1635,46$.

${ }^{69}$ J. de Silhon, Les deux vérités de Silhon. L'une de dieu, et de sa providence, L'autre de l'immortalité de l'ame, ed. J.R. Armogathe, Paris: Fayard, 1991 (Corpus des œuvres de philosophie en langue française), 143-158.

${ }^{70}$ M. Mersenne, Quaestiones celeberrimae in Genesim, cum accurata textus explicatione, Paris: Sebastien Cramoisy, 1623, 399; Id., La vérité des sciences. Contre les sceptiques ou pyrrhoniens, Paris: Toussaint du Bray, 1625 (repr. Stuttgart-Bad Cannstatt: Frommann 1969), 121: 'La seconde erreur d'Aristote se voir dans le 6. chapitre de son livre du monde (encore que tous ne demeurent pas d'accord s'il a fait ce livre) dans lequel il dit que Dieu ne se messe pas des petites choses de ce monde.'
} 
was also Aristotle's opinion. ${ }^{71}$ Despite the fact that Cesalpino, a professor of botany and medicine as well as Clement viII's personal physician, did not directly address Aristotle's view on providence, his view of the prime mover and his position that lower intelligences, or demons, acted in the sublunary regions rather than God himself, made him an emblem for impiety connected to Aristotle. The Dutch theologian Gerard Johannes Vossius (1577-1649) linked Cesalpino's view to Aristotle's, and the English theologian Samuel Parker (1640-1688) thought Cesalpino was an example of how Aristotelian principles could lead to impious philosophy. ${ }^{72}$

Others defended Aristotle by countering the Platonists' polemics. In his $1645 \mathrm{De}$ pietate Aristotelis, Fortunio Liceti (1577-1657), a professor at Padua, described Patrizi as an 'enraged enemy' of Aristotle. Liceti contended that correspondences between Aristotle's theology and the Old Testament could be uncovered through a reading of the De mundo, a work now generally considered spurious, and that by Liceti's time had been rejected as inauthentic by Julius Caesar Scaliger and Daniel Heinsius. ${ }^{73}$ In Liceti's view De mundo shows that Thomas was correct in believing that Aristotle held that there is providence in human affairs (397b30-398a1). Moreover, according to Liceti, Aristotle came to this view because he had read Scripture. ${ }^{74}$

Nevertheless, in a sense Averroes' view prevailed. The historical acrobatics of Liceti convinced few, and leading philologists pointed out differences between Christianity and Aristotle's thought. For example, Guillaume Du Val's synopsis of the Metaphysics, which accompanied Isaac Causabon's and Giulio Pacius' 1619 Greek edition of Aristotle's complete works, interpreted Aristotle as believing that God does not see human actions. Therefore Aristotle was impious because he 'denied divine providence and justice. ${ }^{75} \mathrm{Du}$ Val's judgment, however, was not part of a

\footnotetext{
${ }^{71}$ N. Taurellus, Alpes caesae. Hoc est, Andr. Caesalpini Itali, monstrosa \& superba dogmata, discussa E excussa, Frankfurt: Palthenius, 1597, 31.

${ }^{72}$ G.J. Vossius, De theologia gentili, et physiologia Christiana; sive De origine ac progressu idololatriae; deque naturae mirandis, quibus homo adducitur ad deum, libri ix, Amsterdam: Joan Blaeu, 1668, 267; S. Parker, Disputationes de deo, et providentia divina, London: M. Clark, $1678,67-68$.

${ }^{73}$ See J. Kraye, 'Daniel Heinsius and the Author of De Mundo', in: A.C. Dionisotti, A. Grafton \& J. Kraye (eds), The Uses of Greek and Latin. Historical Essays, London: The Warburg Institute, 1988 (Warburg Institutes surveys and texts, 16), 171-197; and Ead., 'Aristotle's God and the Authenticity of De Mundo: An Early Modern Controversy',Journal of the History of Philosophy, 28 (1990), 339-358.

${ }^{74}$ F. Liceti, De pietate Aristotelis erga deum E homines libri duo, Udine: Schiratti, 1645, 5, $69-70,88$

${ }^{75}$ G. Du Val, Aristotelis operum ... accessit synopseos analyticae universae doctrinae peripateticae, 2 vols, Paris: Typis Regiis, 1619, 2: 122-123: 'Hinc enim manifeste colligeretur,
} 
program to undermine Aristotelianism or systematic theology. Elsewhere he urged his readers to 'marvel at the theology of this pagan man [i.e., Aristotle]' because of its similarities with Christian thought. ${ }^{76}$ While there is some element of the desire to reconcile Christianity with ancient philosophy in Du Val's synopsis, his conclusions depended on textual and philological evidence and not on readings of Thomas or Averroes, as is fitting for an aide to a Greek edition of Aristotle. Yet on this one point regarding providence, his interpretation of Aristotle's Greek coincided with Averroes' reading.

Promoters of new natural philosophies, agreeing with the philologists and Averroes, and ignoring Thomas's interpretations, demonized Aristotle's view on providence. Francis Bacon thought it was a sign of impiety that Aristotle's nature becomes the final cause of his physics, leaving 'no further need of God' and an absence of divine providence in his explanations of the natural world ${ }^{77}$ Following Bacon's line of thought, Samuel Parker wrote in 1678 that those who followed Aristotle 'built their theology on the foundations of his impiety. ${ }^{78}$ Joseph Glanvill (1636-1680) combined these contentions in The Vanity of Dogmatizing, printed in 1661. He contended that, 'the Aristotelian Philosophy is in some things impious, and inconsistent with Divinity' [his emphasis], writing that in the Peripatetic system, 'God was idle. ${ }^{\text {79 }}$ John Webster's 1654 critique of universities noted that Aristotle wrote according to 'Diabolical' instinct and 'denies in the twelfth of his Metaphysicks that God takes care of minute, and small things. ${ }^{\prime 0}$ The Cambridge Platonist Ralph Cudworth (1617-1688), despite preferring Aristotle to Democritus and Descartes, pointed out the superiority of Plato to Aristotle, writing, 'we cannot deny that Aristotle hath been taxed by sundry of the ancients, Christians and others, for not so explicitly asserting these two things, the immortality of human souls and providence over men, as he ought to have done, and his master Plato did. ${ }^{\prime 1}$

Deum non videre actiones nostras ... At haec asserere impium est, \& divinam providentiam iustitiamque tollere.'

${ }^{76} \mathrm{Du}$ Val, Aristotelis operum, 2: 122: 'Mirare, Lectori, hominis Ethnici Theologiam.'

${ }^{77}$ F. Bacon, De augmentis scientiarum, in: The Works of Francis Bacon, 4, ed. J. Spedding, R.L. Ellis \& D.D. Heath, London: Longman, 1860 (repr. Stuttgart-Bad Cannstatt: Frommann, 1962), 363-365.

${ }^{78}$ Parker, Disputationes, iv-v: 'Cum enim unum Aristotelem secuti sint, ipsis Impietatis fundamentis Theologiam suam extruxerunt' [his emphasis].

${ }^{79}$ J. Glanvill, The Vanity of Dogmatizing, London: Henry Eversden, 1661, 183-184.

${ }^{80} \mathrm{~J}$. Webster, Academiarum examen, or, the Examination of Academies, London: Giles Calvert, 1654, 1-2.

${ }^{81}$ R. Cudworth, The True Intellectual System of the Universe: Wherein All the Reason and Philosophy of Atheism Is Confuted, 2 vols, Andover (MA): Gould and Newman, 1837, 1: 115. 
Some living in Catholic countries also described Aristotle in similar negative terms. Nicolas Malebranche (1638-1715) expressed disbelief in the great weight that some thinkers placed in Aristotle's views. The efforts made to determine what Aristotle thought about a question of faith is a sign of an inversion of reason [that] certain men are shocked in philosophy we speak differently from Aristotle, but not troubled if we speak differently from the Gospel, the Fathers, and the Councils in theology.82 Claude Bérigard (1578-1663) in his Circulus pisanus (1643) described Aristotle as impious for his belief in the limited role of the prime mover below the celestial spheres.$^{83}$ Leibniz wrote in comments on Maimonides' Guide for the Perplexed that the 'providence of Aristotle is above the moon', and contrasted his beliefs with the Mu'tazilites, whom he found similar doctrinally to Christians. ${ }^{84}$ Consolidating this idea was Pierre Bayle, who, having noted that Aristotle clashed with Christianity on the 'points of the greatest consequence,' described two such points: the eternity of the universe, and that providence did not 'extend itself to sublunary beings. ${ }^{185}$ Averroes' interpretation of Aristotle became not just accepted as an accurate textual reading, but also as a tool in polemics against Aristotelianism. By attributing to Aristotle an impious view of providence, the alternative philosophies, whether Cartesian or corpuscular, Mosaic or mechanical, could better present themselves as the true philosophy.

\section{CONCLUSION}

Attacking Averroistic, and thereby Aristotelian, views of providence was an opportunistic tactic for discrediting an established philosophical opponent. It was, however, more than just a tactic. Developing a natural philosophy that promoted acceptable theories of providence was central to many early modern innovators in natural philosophy. Descartes, for example, explicitly maintained that God's providence

\footnotetext{
${ }^{82}$ N. Malebranche, The Search after Truth [Recherche de la vérité], tr. Th.M. Lennon \& P.J. Olscamp, Cambridge: Cambridge University Press, 1997 (Cambridge texts in the history of philosophy), 145.

${ }^{83}$ C. Bérigard, Circulus pisanus, de veteri E peripatetica philosophia, Udine: Schiratti, $1643,3$.

${ }^{84}$ Leibniz, Philosophische Schriften, 6/4c: 2493: 'Aristoteli providentia est supra lunam.'

${ }^{85}$ Bayle, Dictionnaire, 1: 327 'Il faut rendre cette justice à ses plus aveugles Sectateurs, qu' ils l'ont abandonné dans les choses où il a choqué le Christianisme. Ces choses sont de la derniere conséquence, puis qu'il a soutenu l'éternité de l'Univers, \& qu'il n'a point cru que la Providence s'étendît sur les Etres sublunaires.'
} 
extended to particular actions of humans. ${ }^{86}$ Robert Boyle (1627-1691) argued that the mechanical philosophy was not incompatible with the proposition 'That God governs the World he has made. ${ }^{87}$ For Boyle, this governing of the world extended not just to human beings but also to 'such Small and Abject Ones, as Flies, Ants Fleas, \&c. ${ }^{88}$ These views he contrasted to 'many (especially Aristotelian) Deists' [his emphasis], who do not even credit God with creating the universe.$^{89}$ Similarly, Robert Hooke (1635-1703) used his microscope in an effort to give experiential evidence for Boyle's view that 'the Wisdom and Providence of the All-wise Creator is not less shewn in these small despicable creatures, Flies and Moths. ${ }^{90}$ For Hooke, the microscope offered empirical evidence for God's providence throughout the sublunary world.

Finally, the culmination of the scientific revolution in the person of Isaac Newton (1643-1727) saw not the promotion of deism but the endorsement of a version of God at odds with Aristotelianism. Newton opposed scholastic philosophy, which he believed had corrupted Christianity by combining Scripture with the metaphysics of heathen philosophers, including Aristotle. ${ }^{91}$ In the words of Alexandre Koyré:

Newton's God is not merely a 'philosophical' God, the impersonal and uninterested First Cause of the Aristotelians ... He is - or, in any case Newton wants him to be - the Biblical God, the effective Master and Ruler of the world created by him. $^{92}$

${ }^{86}$ C.P. Ragland, 'Descartes on Divine Providence and Human Freedom', Archiv für Geschichte der Philosophie, 87 (2005), 159-188.

${ }^{87}$ The Works of Robert Boyle, ed. M. Hunter \& E.B. Davis, 11, London: Pickering \& Chatto, $2000,300$.

${ }^{88}$ The Works of Robert Boyle, 11: 300.

${ }^{89}$ The Works of Robert Boyle, 11: 301.

${ }^{90}$ R. Hooke, Micrographia, or Some physiological descriptions of minute bodies made by magnifying glasses: With observations and inquiries thereupon, London: John Martyn, 1665, 198.

${ }^{91}$ I. Newton, Drafts on the History of the Church (section 5), Ms Jerusalem, National Library of Israel, Yahuda 15.5, 97 ${ }^{\mathrm{r}}$, URL: <http://www.newtonproject.sussex.ac.uk/view/texts/ diplomatic/THEMoo222 >. Cf. R. Iliffe, 'Those “Whose Business It Is to Cavill:" Newton's Anti-Catholicism,' in: J.E. Force \& R.H. Popkin (eds), Newton and Religion: Context, Nature, and Influence, Dordrecht: Kluwer, 1999 (International archives of the history of ideas, 161), 97-119, at 106.

${ }^{92}$ A. Koyré, From the Closed World to the Infinite Universe, Baltimore: Johns Hopkins University Press, 1968 (The Hideyo Noguchi lectures, 7), 225. For Newton's views on providence see: D. Kubrin, 'Newton and the Cyclical Cosmos: Providence and the Mechanical Philosophy', Journal of the History of Ideas, 28 (1967), 325-346; I.B. Cohen, 'Isaac Newton's Principia, the Scriptures, and the Divine Providence', in: S. Morgenbesser, P.C. Suppes \& M.G. White (eds), 
Thus Newton fashioned his system of the universe so that God's rule extends equally everywhere. In the General Scholium that accompanied the second edition of the Principia, Newton described God 'not as the world soul but as lord of all', who is omniscient and omnipresent. Newton held that God 'rules all things, and he knows all things that happen', thereby rejecting the idea of 'a god without dominion, providence, and final causes. ${ }^{193}$ Furthermore, the elimination of the division between celestial and sublunary regions in his physics entailed the incoherence of Averroes' alleged position that God's providence only extended to the planetary orbs. Just as the laws of nature are universal for Newton, God's rule is uniform, affecting the terrestrial and celestial according to the same measure. Newton's natural philosophy solved a number of outstanding problems in natural philosophy. Among them was the development of a system that was in accord with his vision of the divine that included God's providence emanating to terrestrial individuals.

Philosophy, Science, and Method. Essays in Honor of Ernest Nagel, New York: St. Martin's Press, 1969, 523-548; and H. Guerlac, \& M.C. Jacob, 'Bentley, Newton, and Providence: The Boyle Lectures Once More',Journal of the History of Ideas, 30 (1969), 307-318.

${ }^{93}$ I. Newton, The Principia: Mathematical Principles of Natural Philosophy, tr. I.B. Cohen \& A. Whitman, Berkeley (CA): University of California Press, 1999, 940-942. 


\section{BIBLIOGRAPHY}

\section{UNPUBLISHED WORKS}

Anonymous (= Siger of Brabant?), Quaestiones super Physicam, Ms Erfurt, Universitätsbibliothek, Dep. Erf., CA F. 349, $75^{\text {ra }}-117^{\text {rb }}$.

Anonymous, Quaestiones super Physicam, Ms Cambridge, Gonville and Caius College Library, $367,120^{\mathrm{ra}}-125^{\mathrm{vb}}, 136^{\mathrm{ra}}-151^{\mathrm{vb}}$.

Anonymous, Quaestiones super Physicam, Ms Cambridge, Gonville and Caius College Library, 513, $1^{\text {ra }}-83^{\text {rb }}$.

Anonymous, Quaestiones super Physicam, Ms Kassel, Gesamthochschul-, Landesund Murhardsche Bibliothek, Phys. $2^{\circ} 11,1^{\mathrm{ra}}-35^{\mathrm{rb}}$.

Anonymous, Quaestiones super Physicam, MS London, British Library, Burney 358, $85^{\mathrm{ra}}-108^{\mathrm{vb}}$.

Anonymous, Quaestiones super Physicam, Ms Montpellier, Bibliothèque interuniversitaire, Sect. de médicine, H. 293, $1^{\mathrm{va}}-81^{\mathrm{ra}}$.

Anonymous, Quaestiones super Physicam, MS Oxford, Merton College Library, 272, $136^{\mathrm{ra}}-174 \mathrm{~B}^{\mathrm{rb}}$.

Anonymous, Quaestiones super Physicam, Ms Oxford, Merton College Library, 272, $119^{\text {ra }}-135 C^{\text {rb }}$.

Anonymous, Quaestiones super Physicam, Ms Oxford, New College Library, 285, $118^{\mathrm{ra}}-162^{\mathrm{ra}}$.

Anonymous, Quaestiones super Physicam, Ms Padova, Biblioteca Antoniana, XVII $380,1^{\mathrm{ra}}-62^{\mathrm{ra}}$.

Anonymous, Quaestiones super Physicam, Ms Paris, Bibliothèque Mazarine, 3493, $1^{\mathrm{ra}}-93^{\mathrm{vb}}$.

Anonymous, Quaestiones super Physicam, Ms Paris, Bibliothèque Nationale de France, lat. $14698,83^{\text {ra }}-129 \mathrm{~A}^{\mathrm{r}}$.

Anonymous, Quaestiones super Physicam, Ms Siena, Biblioteca Comunale degli Intronati, L.III.21, $1^{\mathrm{ra}}-92^{\mathrm{ra}}$.

Galfridus de Aspall, Quaestiones super De caelo et mundo, Ms Todi, Biblioteca Comunale, $23,168^{\text {ra }}-240^{\text {vb }}$.

Galfridus de Aspall, Quaestiones super Physicam, Ms Oxford, Merton College Library, $272,88^{\text {ra }}-118^{\text {vb }}$.

Guillelmus de Clifford, Compilationes super librum Physicorum Aristotelis, MS Cambridge, Peterhouse Library, $157, \mathrm{I}, 43^{\mathrm{ra}}-104^{\mathrm{va}}$.

Magister /// de <C.idene?>, Quaestiones super Physicam, Ms Leipzig, Universitätsbibliothek, 1386, $77^{\mathrm{vb}}-91^{\mathrm{ra}}$.

Magister <Pa? $>$, Quaestiones super Physicam, Ms Leipzig, Universitätsbibliothek, $1386,41^{\mathrm{ra}}-76^{\mathrm{ra}}$. 
Walter Burley, Expositio et Quaestiones Physicorum, Ms Cambridge, Gonville and Caius College Library, 448 (409), 172-543.

\section{PUBLISHED WORIS}

\section{II.1. Authors before ca. 1500}

Al-Bițrūğì, De motibus celorum, ed. F.J. Carmody, Berkeley [etc.]: University of California Press, 1952.

Al-Bițrūğī, On the Principles of Astronomy, ed. B.R. Goldstein, New Haven [etc.]: Yale University Press, 1971 (Yale studies in the history of science and medicine, 7).

Albert the Great, De anima, ed. C. Stroick, Münster: Aschendorff, 1968 (Opera omnia, 7/1).

Albert the Great, De caelo et mundo, ed. P. Hossfeld, Münster: Aschendorff, 1971 (Opera omnia, 5/1).

Albert the Great, Metaphysica. Libri VI-XIII, ed. B. Geyer, Münster: Aschendorff, 1964 (Opera omnia, 16/2).

Albert the Great, Physica. Libri I-IV, ed. P. Hossfeld, Münster: Aschendorff, 1987 (Opera omnia, 4/1).

Albert the Great, Physica. Libri v-viII, ed. P. Hossfeld, Münster: Aschendorff, 1993 (Opera omnia, 4/2).

Alexander of Aphrodisias, 'Maqālat al-Iskandar al-Afrūdīsĩ fĩ l-'aql 'alā ra'y Arisțūtạtāis', in: 'A. Badawī, Šurūḥ 'alā Arisțū mafqūda fì l-yūnāniyya wa-rasā’il uhrā-Commentaires sur Aristote perdus et autres épîtres, Beyrouth: Dar elMachreq, 1971, 31-42.

Alexander of Aphrodisias, De anima II (Mantissa), ed. and tr. P. Accattino \& P. Cobetto Ghiggia, Alessandria: Edizioni dell'Orso, 2005 (Classica philosophica et iuridica. Testi, 1).

Alexander of Aphrodisias, De anima liber cum mantissa, ed. I. Bruns, Berlin: Reimer, 1887 (Supplementum Aristotelicum, 2/1).

Alexander of Aphrodisias, De anima libri mantissa. A new edition of the Greek text with introduction and commentary, ed. R.W. Sharples, Berlin [etc.]: De Gruyter, 2008 (Peripatoi, 21).

Alexander of Aphrodisias, De intellectu, ed. and tr. P. Accattino, Torino: Thélème, 2001.

Alexander of Aphrodisias, De l'âme II (Mantissa), tr. R. Dufour, Québec: Presses de l'Université Laval, 2013 (Zêtêsis. Textes et essais).

Alexander of Aphrodisias, De l'âme, tr. M. Bergeron \& R. Dufour, Paris: Vrin, 2008 (Textes \& commentaires). 
Alexander of Aphrodisias, L'anima, tr. P. Accattino \& P. Donini, Roma: Laterza, 1996 (Biblioteca universale Laterza, 447).

Alexander of Aphrodisias, La Provvidenza. Questioni sulla provvidenza, ed. S. Fazzo, tr. M. Zonta, Milano: Rizzoli, 1999 (Biblioteca universale Rizzoli, L1289).

Alexander of Aphrodisias, On the Soul. Part 1: Soul as Form of the Body, Parts of the Soul, Nourishment, and Perception, tr. V. Caston, London: Bristol Classical Press, 2012 (Ancient commentators on Aristotle).

Alexander of Aphrodisias, Supplement to 'On the Soul', tr. R.W. Sharples, Ithaca (NY): Cornell University Press, 2004 (Ancient commentators on Aristotle).

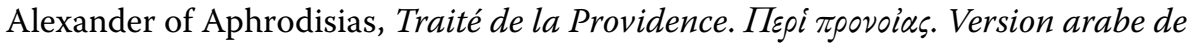
Abū Bišr Mattä ibn Yünus, ed. and tr. P. Thillet, Paris: Verdier, 2003.

Anonymous (= Siger of Brabant), Quaestiones super Physicam, Ms Paris, Bibliothèque Nationale de France, lat. 16297, $70^{\text {va }}-73^{\text {va }}, 76^{\text {ra }}-76^{\text {vb }}$ (ed. in: D. Calma, Etudes sur le premier siècle de l'averroïsme latin: approches et textes inédits, Turnhout: Brepols, 2011 [Studia artistarum, 31], 133-160).

Aristotle, Categoriae, ed. L. Minio-Paluello, Oxford: Clarendon Press, 1949 (Scriptorum classicorum bibliotheca Oxoniensis).

Aristotle, De l'âme, ed. A. Jannone, tr. E. Barbotin, Paris: Les Belles Lettres, 1980 ( $\left.{ }^{1} 1966\right)$.

Aristotle, Physics, tr. R.P. Hardie \& R.K. Gaye, in: J. Barnes, (ed.), The Complete Works of Aristotle, The Revised Oxford Translation, Princeton: Princeton University Press, 1984 (Bollingen Series 71/2), 315-446.

Aristotle, Physics: Book VIII, tr. D.W. Graham, Oxford: Clarendon Press, 1999 (Clarendon Aristotle series).

Aristotle, Physics: Books I E II, tr. W. Charlton, Oxford: Clarendon Press, 1970 (Clarendon Aristotle series).

Aristotle, Physics: Books III \& IV, tr. E. Hussey, Oxford: Clarendon Press, 1983 (Clarendon Aristotle series).

Averroes, Aristotelis opera cum Averrois commentariis, 9 vols, Venezia: Apud Junctas, 1562-1574 (repr. Frankfurt am Main: Minerva, 1962).

Averroes, Commentarium magnum in Aristotelis De anima libros, ed. F.S. Crawford, Cambridge (MA): The Medieval Academy of America, 1953 (Corpus commentariorum Averrois in Aristotelem. Versionum latinarum 6/1).

Averroes, Commentary on Aristotle's Book on the Heaven and the Universe: Sharh kitāb al-samā' wa-l-älam. With an introduction by Gerhard Endress. Reproduced from MS 11821, National Library, Tunis (Ahmadiyya Fund, 5538), Frankfurt am Main: Institute for the history of Arabic-Islamic science at the Johann Wolfgang Goethe University, 1994 (Publications of the Institute for the history of Arabic-Islamic science. Series C, Facsimile editions, 57).

Averroes, Commentum magnum super libro De celo et mundo Aristotelis, ed. F.J. Car- 
mody \& R. Arnzen, 2 vols, Leuven: Peeters, 2003 (Recherches de Théologie et Philosophie médiévales. Bibliotheca, 4).

Averroes, Compendio de Metafísica, ed. C. Quirós Rodríguez, Madrid: Real Academia de Ciencias morales y políticas, 1919.

Averroes, De substantia orbis. Critical Edition of the Hebrew Text with English Translation and Commentary, ed. and tr. A. Hyman, Cambridge (MA): The Medieval Academy of America - Jerusalem: The Israel Academy of Sciences and Humanities, 1986 (Medieval Academy books, 96).

Averroes, In Metaphysicam, in: Aristotelis opera cum Averrois commentariis, 8, Venezia: Apud Junctas, 1562-1574 (repr. Frankfurt am Main: Minerva, 1962).

Averroes, In Physicam, in: Aristotelis opera cum Averrois commentariis, 4, Venezia: Apud Junctas, 1562-1574 (repr. Frankfurt am Main: Minerva, 1962).

Averroes, L'intelligence et la pensée. Grand Commentaire du De anima, Livre III (429a10-435b25), tr. A. de Libera, Paris: GF Flammarion, 1998.

Averroes, L'Islam et la raison. Anthologie de textes juridiques, théologiques et polémiques, tr. M. Geoffroy, Paris: GF Flammarion, 2000.

Averroes, La Béatitude de l'âme. Editions, traductions annotées, études doctrinales et historiques d'un traité d'Averroès', ed. M. Geoffroy \& C. Steel, Paris: Vrin, 2001 (Sic et non).

Averroes, Long Commentary on the De anima of Aristotle, tr. R.C. Taylor \& Th.A. Druart, New Haven [etc.]: Yale University Press, 2009 (Yale library of medieval philosophy).

Averroes, On Aristotle's Metaphysics. An Annotated Translation of the So-called Epitome, ed. R. Arnzen, Berlin [etc.]: De Gruyter, 2010 (Scientia Graeco-Arabica, 5).

Averroes, Sermo de substantia orbis, in: Aristotelis opera cum Averrois commentariis, 9, Venezia: Apud Junctas, 1562-1574 (repr. Frankfurt am Main: Minerva, 1962), $3^{\mathrm{ra}}-14^{\mathrm{vb}}$.

Averroes, Tafsïr mā ba'd aț-tabī'at ('Grand Commentaire de la Métaphysique'), ed. M. Bouyges, Beyrouth: Dar El-Machreq, ${ }^{2} 1973$.

Averroes, Tafsir mā ba'd al-tabīa, ed. M. Bouyges, 3 vols, Beirut: Imprimerie Catholique, 1938-1952 (Bibliotheca Arabica Scholasticorum. Serie arabe, 5-7).

Averroes, Tahafot at-Tahafot. L'incohérence de l'Incohérence, ed. M. Bouyges, Beirut: Dar el-Machreq, ${ }^{3} 1992$.

Averroes, Talhis al-samā' wa-l-'álam, ed. Ğ. al-'Alawī, Fās: Faculté des Lettres de Fez, 1984.

Averroes, Talhịs kitāb al-nafs li-Abì l-Walìd Ibn Rušd wa-arba' rasā'il, ed. F. alAhwānī, Cairo: Maktabat al-nahḍa al-mișriyya, 1950.

Averroes, Über den Intellekt. Auszüge aus seinen drei Kommentaren zu Aristoteles' De anima. Arabisch, Lateinisch, Deutsch, tr. D. Wirmer, Freiburg [etc.]: Herder, 2008 (Herders Bibliothek der Philosophie des Mittelalters, 15). 
Avicenna, Liber de Philosophia prima sive Scientia divina, ed. S. Van Riet, 3 vols, Leuven: Peeters - Leiden [etc.]: Brill, 1977-1983.

Avicenna, Liber primus naturalium: Tractatus primus de causis et principiis naturalium, ed. S. Van Riet, Louvain-la-Neuve: Peeters - Leiden [etc.]: Brill, 1992.

Bernard of Verdun, Tractatus super totam astrologiam, ed. P. Hartmann, Werl: Coelde, 1961 (Franziskanische Forschungen, 15).

Bonaventure, Collationes in Hexaëmeron, Ad Claras Aquas (Quarrachi): Collegium S. Bonaventura, 1891 (Opera omnia, 5), 327-454.

Bonaventure, In secundum librum Sententiarum, Ad Claras Aquas (Quarrachi): Collegium S. Bonaventura, 1885 (Opera omnia, 2).

Calcidius, Timaeus a Calcidio translatus commentarioque instructus, Editio altera, ed. J.H. Waszink, Leiden [etc.]: Brill, 1975 (Plato latinus, 4).

Giles of Rome, Commentaria in octo libros Phisicorum Aristotelis, Venezia: Andreas de Torresanis, 1502 (repr. Frankfurt am Main: Minerva, 1968).

Giles of Rome, Errores philosophorum, ed. J. Koch, tr. J.O. Riedl, Milwaukee (wI): Marquette University Press, 1944.

Giles of Rome, Quaestiones super primo libro De generatione et corruptione, Venezia: Gregorius de Gregoriis, 1505 (repr. Frankfurt am Main: Minerva, 1970).

Gregory of Rimini, Lectura super primum et secundum Sententiarum, ed. A.D. Trapp, V. Marcolino \& M. Santos-Noya, 2: Super primum (dist. 7-17), Berlin [etc.]: De Gruyter, 1982 (Spätmittelalter und Reformation, 7).

John Blund, Tractatus de anima, ed. D.A. Callus \& R.W. Hunt, London [etc.]: Oxford University Press, 1970 (Auctores Britannici Medii Aevi, 2).

John Buridan, In Metaphysicen Aristotelis quaestiones argutissimae, Paris: Jodocus Badius, 1518 (repr. [with the wrong date 1588 on the titlepage] Frankfurt am Main: Minerva, 1964).

John Buridan, Quaestiones in duos libros Aristotelis Posteriorum analyticorum, ed. H. Hubien <URL: http://buridanica.org/texts/QQ_in_Post_An.txt>.

John Buridan, Quaestiones super octo libros Physicorum (secundum ultimam lecturam), Libri I-II, ed. M. Streijger \& P.J.J.M. Bakker, Leiden [etc.]: Brill, 2015 (Medieval and early modern science, 25).

John Duns Scotus, Ordinatio, II, dist. 1-3, Città del Vaticano 1973 (Opera omnia, 7). John of Jandun, Quaestiones in duodecim libros Metaphysicae, Venezia: Hieronymus Scotus, 1553 (repr. Frankfurt am Main: Minerva, 1966).

John of Jandun, Quaestiones super 8 libros Physicorum Aristotelis, Venezia: Apud Junctas, 1551 (repr. Frankfurt am Main: Minerva, 1969).

John Philoponus (Pseudo), In Aristotelis De anima libros commentaria, ed. M. Hayduck, Berlin: Reimer, 1897 (Commentaria in Aristotelem Graeca, 15).

John Philoponus, Commentaire sur le De anima d'Aristote. Traduction de Guillaume de Moerbeke, ed. G. Verbeke, Leuven: Publications Universitaires - Paris: 
Béatrice-Nauwelaerts, 1966 (Corpus latinum commentariorum in Aristotelem graecorum, 3).

John Philoponus, De aeternitate mundi, in: C. Scholten (ed. and tr.), Johannes Philoponos. De aeternitate mundi - Über die Ewigkeit der Welt, 1, Turnhout: Brepols, 2009 (Fontes Christiani, 64/1).

Moses Maimonides, Le guide des égarés, tr. S. Munk, Paris: Verdier, 1979.

Ptolemy, Opera astronomica minora, ed. J.L. Heiberg, Leipzig: Teubner, 1907 (Opera quae extant omnia, 2).

Richard Rufus of Cornwall, In Physicam Aristotelis, ed. R. Wood, Oxford [etc.]: Oxford University Press, 2003 (Auctores Britannici Medii Aevi, 16).

Robert Grosseteste, Hexaëmeron, ed. R.C. Dales \& S. Gieben, London [etc.]: Oxford University Press, 1982 (Auctores Britannici Medii Aevi, 6).

Roger Bacon, Opus Maius, ed. S. Jebb, London: William Bowyer, 1733.

Roger Bacon, Opus Maius, tr. R.B. Burke, 2 vols, Philadelphia [etc.]: University of Pennsylvania Press, 1928.

Roger Bacon, Questiones supra libros octo Physicorum, ed. F.M. Delorme \& R. Steele, Oxford: Clarendon Press, 1935 (Opera hactenus inedita, 13).

Roger Bacon, Questiones supra libros quatuor Physicorum, ed. F.M. Delorme \& R. Steele, Oxford: Clarendon Press, 1928 (Opera hactenus inedita, 8).

Siger of Brabant, Quaestiones in Physicam, in: Id., Ecrits de logique, de morale et de physique, ed. B.C. Bazán, Leuven: Publications Universitaires - Paris: Béatrice-Nauwelaerts, 1974 (Philosophes médiévaux, 14).

Siger of Brabant, Quaestiones in Physicam, Ms Città del Vaticano, Biblioteca Apostolica Vaticana, Borgh. 114, $15^{\text {ra }}-18^{\text {va }}$ (ed. A. Zimmermann, in: Siger of Brabant, Ecrits de logique, de morale et de physique, ed. B.C. Bazán, Leuven: Publications Universitaires - Paris: Béatrice-Nauwelaerts, 1974 [Philosophes médiévaux, 14], 141-184).

Siger of Brabant, Quaestiones in tertium De anima, De anima intellectiva, De aeternitate mundi, ed. B.C. Bazán, Leuven: Publications Universitaires - Paris: Béatrice-Nauwelaerts, 1972 (Philosophes médiévaux, 13).

Simplicius, In Aristotelis De caelo commentaria, ed. J.L. Heiberg, Berlin: G. Reimer, 1894 (Commentaria in Aristotelem Graeca, 7).

Simplicius, In Aristotelis Physicorum libros commentaria, ed. H. Diels, 2 vols, Berlin: G. Reimer, 1882-1895 (Commentaria in Aristotelem Graeca, 9-10).

Thomas Aquinas, In Aristotelis libros De caelo et mundo expositio, ed. R.M. Spiazzi, Torino [etc.]: Marietti, 1952.

Thomas Aquinas, In duodecim libros Metaphysicorum Aristotelis expositio, ed. M.-R. Cathala \& R.M. Spiazzi, Torino [etc.]: Marietti, 1950.

Thomas Aquinas, In octo libros Physicorum expositio, ed. P.M. Maggiòlo, Torino [etc.]: Marietti, 1954. 
Thomas Aquinas, Quaestio disputata de spiritualibus creaturis, ed. J. Cos, Roma: Commissio Leonina - Paris: Editions du Cerf, 2000 (Opera omnia, 24/2).

Thomas Aquinas, Scriptum super primum librum Sententiarum, ed. P. Mandonnet, Paris: Lethellieux, 1929.

Thomas Aquinas, Scriptum super secundum librum Sententiarum, ed. P. Mandonnet, Paris: Lethellieux, 1929.

Thomas Aquinas, Summa contra Gentiles, Roma [etc.]: Commissio Leonina, 19181930 (Opera omnia, 13-15).

Thomas Aquinas, Summa contra Gentiles, Torino [etc.]: Marietti, 1961.

Thomas Aquinas, Summa theologiae, ed. P. Caramello, Torino [etc.]: Marietti, 1952.

Walter Burley, Expositio in libros octo De phisico auditu, Venezia: Simon de Luere, 1501 (repr. Hildesheim: Olms, 1972).

William of Ockham, Expositio in libros Physicorum Aristotelis. Libri IV-VIIII, ed. R. Wood, R. Green, G. Gál, J. Giermek, F. Kelley, G. Leibold \& G. Etzkorn, St. Bonaventure (NY): St. Bonaventure University, 1985 (Opera philosophica, 5).

William of Ockham, Expositio in libros Physicorum Aristotelis. Prologus et libri I-III, ed. V. Richter \& G. Leibold, St. Bonaventure (NY): St. Bonaventure University, 1985 (Opera philosophica, 4).

William of Ockham, Quaestiones in libros Physicorum Aristotelis, ed. S. Brown, St. Bonaventure (NY): St. Bonaventure University, 1984 (Opera philosophica, 6).

\section{II.2. Authors after ca. 1500}

Accattino, P., 'Alessandro di Afrodisia e la trasmissione della forma nella riproduzione animale,'Atti della Accademia delle Scienze di Torino, classe di scienze morali, storiche e filologiche, 122 (1988), 79-94.

Accattino, P., 'Generazione dell'anima in Alessandro di Afrodisia, De anima 2.1011.1?', Phronesis, 40 (1995), 182-201.

Achillini, A., Opera omnia, Venezia: Hieronymus Scotus, 1568.

Adam, Ch., \& P. Tannery (eds), Euvres de Descartes, Paris: Vrin, 1996.

Aho, T., \& M. Yrjönsuuri, 'Late Medieval Logic', in: L. Haaparanta (ed.), The Development of Modern Logic, Oxford [etc.]: Oxford University Press, 2009, 11-77.

Aiello, A., \& R. Wielockx, Goffredo di Fontaines Aspirante Baccelliere Sentenziario: Le autografe Notule de scientia theologie e la cronologia del ms. Paris BnF Lat. 16297, Turnhout: Brepols, 2008 (Corpus christianorum. Autographa Medii Aevi, 6).

Al-'Alawī, Ğ., al-Matn al-rušdì, Casablanca: Țūbqāl, 1986.

Bacon, F., De augmentis scientiarum, in: The Works of Francis Bacon, 4, ed. J. Spedding, R.L. Ellis \& D.D. Heath, London: Longman, 1860 (repr. Stuttgart-Bad Cannstatt: Frommann, 1962), 273-498.

Badawī, 'A., Arisțū 'inda l-'arab, Cairo: Maktabat al-nahḍa al-mișriyya, 1947. 
Balme, D., 'Teleology and Necessity', in: A. Gotthelf \& J.G. Lennox (eds), Philosophical Issues in Aristotle's Biology, Cambridge: Cambridge University Press, 1987, 275-286.

Barker, P., 'Copernicus and the Critics of Ptolemy', Journal for the History of Astronomy, 30 (1999), 343-358.

Basso, S., Philosophiae naturalis adversus Aristotelem libri xii, Genève: Petrus de la Rouière, 1621.

Bayle, P., Dictionnaire historique et critique, $5^{\text {th }}$ ed., 4 vols, Amsterdam: P. Brunel, 1740.

Bazán, B.C., 'L' authenticité du De intellectu attribué à Alexandre d'Aphrodise', Revue philosophique de Louvain, 71 (1973), 468-487.

Bazán, B.C., 'Radical Aristotelianism in the Faculty of Arts. The case of Siger of Brabant', in: L. Honnefelder, R. Wood, M. Dreyer \& M.-A. Aris (eds), Albertus Magnus und die Anfänge der Aristoteles-Rezeption im lateinischen Mittelalter: von Richardus Rufus bis zu Franciscus de Mayronis, Münster: Aschendorff, 2005 (Subsidia Albertina, 1), 585-629.

Beck, A.J., Gisbertus Voetius (1589-1676): sein Theologieverständnis und seine Gotteslehre, Göttingen: Vandenhoeck \& Ruprecht, 2007 (Forschungen zur Kirchen- und Dogmengeschichte, 92).

Bérigard, C., Circulus pisanus, de veteri E peripatetica philosophia, Udine: Schiratti, 1643.

Bertolacci, A., The Reception of Aristotle's Metaphysics in Avicenna's Kitāb al-Šifä̀': A Milestone of Western Metaphysical Thought, Leiden [etc.]: Brill, 2006 (Islamic philosophy, theology, and science, 63).

Bessarion, J., In calumniatorem Platonis libri IV, ed. L. Mohler, Paderborn: Schöningh, 1927.

Boer, S.W. de, 'The Importance of Atomism in the Philosophy of Gerard of Odo (o.f.M.),' in: C. Grellard \& A. Robert (eds), Atomism in Late Medieval Philosophy and Theology, Leiden [etc.]: Brill, 2009 (Medieval and early modern science, 9), 85-106.

Bordt, M., Aristoteles' Metaphysik XII, Darmstadt: Wissenschaftliche Buchgesellschaft, 2006 (Werkinterpretationen).

Bouwsma, W.J., Concordia Mundi: The Career and Thought of Guillaume Postel (1510-1581), Cambridge (MA): Harvard University Press, 1957 (Harvard Historical monographs, 33).

Boyle, R., The Works of Robert Boyle, ed. M. Hunter \& E.B. Davis, 14 vols, London: Pickering \& Chatto, 2000.

Brenet, J.-B., 'Acquisition de la pensée et acquisition de l'acte chez Averroès. Une lecture croisée du Grand Commentaire au De anima et du Kitāb al-Kašf 'an manāhiğ al-adilla', in: L.X. López Fajeat \& J.A. Tellkamp (eds), Philosophical 
Psychology in Arabic Thought and the Latin Aristotelianism of the $13^{\text {th }}$ Century, Paris: Vrin, 2013, 111-139.

Brenet, J.-B., 'Averroès et "la question de Théophraste." La puissance et l'être de l'intellect matériel', forthcoming.

Brenet, J.-B., 'Averroès et l' intellect matériel diaphane. Remarques sur une analogie variable', in: A. Speer \& D. Wirmer (eds), From Cordoba to Cologne: Transformation and Translation, Transmission and Edition of Averroes's works, Berlin [etc.]: De Gruyter, forthcoming.

Brenet, J.-B., 'John of Jandun', in: H. Lagerlund (ed.), Encyclopedia of Medieval Philosophy. Philosophy between 500 and 150o, Dordrecht: Springer, 2011, 1: 626-629.

Brenet, J.-B., 'Siger de Brabant et la notion d'operans intrinsecum: un coup de maitre?', Revue des sciences philosophiques et théologiques, 97 (2013), 3-36.

Brenet, J.-B., La matière et l'intellect. Alexandre d'Aphrodise lu par Averroès, forthcoming.

Brenet, J.-B., Les possibilités de jonction. Averroès - Thomas Wylton, Berlin [etc.]: De Gruyter, 2013 (Scientia Graeco-Arabica, 10).

Brenet, J.-B., Transferts du sujet: la noétique d'Averroès selon Jean de Jandun, Paris: Vrin, 2003 (Sic et non).

Bridges, J.H. (ed.), The 'Opus Majus' of Roger Bacon, Oxford: Clarendon Press, 1897-1900 (repr. Frankfurt am Main: Minerva, 1964).

Calma, D., Etudes sur le premier siècle de l'averroïsme latin: approches et textes inédits, Turnhout: Brepols, 2011 (Studia artistarum, 31).

Campanella, T., De gentilismo non retinendo, Paris: Dubray, 1636.

Campanini, M., 'Edizioni e traduzioni di Averroè tra XIV e xvı secolo', in: J. Hamesse \& M. Fattori (eds), Lexiques et glossaires philosophiques de la Renaissance, Louvainla-Neuve: Fédération Internationale des Instituts d'Etudes Médiévales, 2004 (Textes et études du Moyen Age, 23), 21-42.

Cano, M., De locis theologicis libri XII, Salamanca: Mathias Gastius, 1563.

Carmody, F.J., 'The Planetary Theory of Ibn Rushd', Osiris, 10 (1952), 556-586.

Caston, V., 'Epiphenomenalisms, Ancient and Modern', Philosophical Review, 106/3 (1997), 309-363.

Cerami, C., 'Le commun avant le propre. Le rôle de Seconds Analytiques i 4-5 dans l'organisation du corpus de philosophie naturelle d'après Averroès', in: A. Speer \& D. Wirmer (eds), From Cordoba to Cologne: Transformation and Translation, Transmission and Edition of Averroes's Works, Berlin [etc.]: De Gruyter, forthcoming.

Cerami, C., 'Signe physique, signe métaphysique. Averroès contre Avicenne sur le statut épistémologique des sciences de l' être', in: C. Cerami (ed.), Nature et Sagesse. Les rapports entre physique et métaphysique dans la tradition aristotélicienne, Leuven: Peeters, 2014 (Aristote: traductions et études), 429-473. 
Cerami, C., Génération et Substance: Aristote et Averroès entre physique et métaphysique, Berlin [etc.]: De Gruyter, 2015 (Scientia Graeco-Arabica).

Chase, M., 'Philoponus' Cosmology in the Arabic Tradition,' Recherches de Théologie et Philosophie médiévales, 79/2 (2012), 271-306.

Clagett, M., Nicole Oresme and the Medieval Geometry of Qualities and Motions. A Treatise on the Uniformity and Difformity of Intensities Known as Tractatus de configurationibus qualitatum et motuum, Madison (WI): University of Wisconsin Press, 1968 (Publications in medieval science, 12).

Cohen, I.B., 'Isaac Newton's Principia, the Scriptures, and the Divine Providence, in: S. Morgenbesser, P.C. Suppes \& M.G. White (eds), Philosophy, Science, and Method. Essays in Honor of Ernest Nagel, New York: St. Martin's Press, 1969, 523-548.

Constant, E.A., 'A Reinterpretation of the Fifth Lateran Council Decree Apostolici Regiminis (1513),' The Sixteenth Century Journal, 33 (2002), 353-379.

Cooper, J.M., 'Aristotle on Natural Teleology', in: M. Schofield \& M. Craven Nussbaum (eds), Language and Logos. Studies in ancient Greek philosophy presented to G.E.L. Owen, Cambridge: Cambridge University Press, 1982, 197222.

Cremonini, C., Apologia dictorum Aristotelis de quinta caeli substantia adversus Xenarcum, Ioannem Grammaticum, E alios, Venezia: Meietti, 1616.

Crosby, H.L., Jr., ed., Thomas Bradwardine. His Tractatus de proportionibus: Its Significance for the Development of Mathematical Physics, Madison (wI): University of Wisconsin Press, 1955 (Publications in medieval science, 2).

Cudworth, R., The True Intellectual System of the Universe: Wherein All the Reason and Philosophy of Atheism Is Confuted, 2 vols, Andover (MA): Gould and Newman, 1837.

Dales, R.C., 'The De-Animation of the Heavens in the Middle Ages,'Journal of the History of Ideas, 41 (1980), 531-550.

Davidson, H.A., 'John Philoponus as a Source of Medieval Islamic and Jewish Proofs of Creation,'Journal of the American Oriental Society, 89 (1969), 357-391.

Davidson, H.A., Alfarabi, Avicenna, and Averroes, on Intellect. Their Cosmologies, Theories of the Active Intellect, and Theories of Human Intellect, New York [etc.]: Oxford University Press, 1992.

Davidson, H.A., Proofs for Eternity, Creation and the Existence of God in Medieval Islamic and Jewish Philosophy, New York [etc.]: Oxford University Press, 1987.

De Libera, A., Métaphysique et noétique: Albert le Grand, Paris: Vrin, 2005.

De Mornay (Du Plessis), Ph., De veritate religionis Christianae, adversus atheos, Epicureos, ethnicos, Iudaeos, Mahumedistas, \& caeteros infideles, Leiden: Andries Clouck, 1605 . 
De Raei, J., Clavis philosophiae naturalis seu Introductio ad naturae contemplationem Aristotelico-Cartesiana, Leiden: J. \& D. Elzevier, 1654.

De Silhon, J., Les deux vérités de Silhon. L'une de dieu, et de sa providence, L'autre de l'immortalité de l'ame, ed. J.R. Armogathe, Paris: Fayard, 1991 (Corpus des œuvres de philosophie en langue française).

De' Vieri, F., Vere conclusioni di Platone conformi alla Dottrina Christiana et a quella d'Aristotile, Firenze: Georgio Marescotti, 1590.

Dekker, D.-J., 'Time and Motion in Walter Burley's late Expositio on Aristotle's Physics,' Early Science and Medicine, 6/3 (2001), 185-203.

Des Chene, D., Physiologia: Natural Philosophy in Late Aristotelian and Cartesian Thought, Ithaca (NY): Cornell University Press, 1996.

Dhanani, A., The Physical Theory of Kaläm. Atoms, Space, and Void in Basrian Mu'tazili Cosmology, Leiden [etc.]: Brill, 1994 (Islamic philosophy, theology, and science, 14).

Donati, S., 'Commenti parigini alla Fisica degli anni 1270-1300 ca.' in: A. Speer (ed.), Die Bibliotheca Amploniana. Ihre Bedeutung im Spannungsfeld von Aristotelismus, Nominalismus und Humanismus, Berlin [etc.]: De Gruyter, 1995 (Miscellanea Mediaevalia, 23), 136-256.

Donati, S., 'Goffredo di Aspall e alcuni commenti anonimi ai Libri naturales nei mss. London, Wellcome Hist. Med. Libr., 333 e Todi, BC, 23 (Qq. super I De gen. et corr.; Qq. super Phys. V, VI), Parte I', Documenti e studi sulla tradizione filosofica medievale, 23 (2012), 245-320;

Donati, S., 'Goffredo di Aspall e alcuni commenti anonimi ai Libri naturales nei mss. London, Wellcome Hist. Med. Libr., 333 e Todi, BC, 23 (Qq. super I De gen. et corr.; Qq. super Phys. V, VI), Parte II', Documenti e studi sulla tradizione filosofica medievale, 24 (2013), 219-418.

Donati, S., 'La discussione sull' unità del concetto di ente nella tradizione di commento della Fisica: commenti parigini degli anni 1270-1315 ca.', in: M. Pickavé (ed.), Die Logik des Transzendentalen. Festschrift für Jan A. Aertsen zum 65. Geburtstag, Berlin [etc.]: De Gruyter, 2003 (Miscellanea Mediaevalia, 30), 6o139.

Donati, S., 'Per lo studio dei commenti alla Fisica del XIII secolo. I: Commenti di probabile origine inglese degli anni 1250-1270 ca.', Documenti e studi sulla tradizione filosofica medievale, 2 (1991), 361-441; 4 (1993), 25-133.

Donati, S., 'Pseudoepigraha in the Opera hactenus inedita Rogeri Baconi? The Commentaries on the Physics and on the Metaphysics', in: O. Weijers \& J. Verger (eds), Les débuts de l'enseignement universitaire à Paris (1200-1245 environ), Turnhout: Brepols, 2013 (Studia artistarum, 38), 153-203.

Donati, S., \& C. Trifogli, 'Natural Philosophy', in: P. Eardley \& C.F. Briggs (eds), The Brill Companion to Giles of Rome, Leiden [etc.]: Brill, forthcoming. 
Du Val, G., Aristotelis operum ... accessit synopseos analyticae universae doctrinae peripateticae, 2 vols, Paris: Typis Regiis, 1619.

Duba, W., 'The Souls after Vienne: Franciscan Theologians' Views on the Plurality of Forms and the Plurality of Souls, ca. 1315-1330,' in: P.J.J.M. Bakker, S.W. de Boer \& C. Leijenhorst (eds), Psychology and the Other Disciplines: A Case of Cross-Disciplinary Interaction (1250-1750), Leiden [etc.]: Brill, 2012 (Medieval and early modern science, 19), 171-272.

Duhem, P., Le système du monde. Histoire des doctrines cosmologiques de Platon à Copernic, 10 vols, Paris: Hermann, 1913-1959.

Duhem, P., Un fragment inédit de l'Opus tertium de Roger Bacon, précédé d'une étude sur ce fragment, Quaracchi: Collegium S. Bonaventurae, 1909.

Endress, G., 'Alexander Arabus on the First Cause. Aristotle's First Mover in an Arabic Treatise Attributed to Alexander of Aphrodisias,' in: C. D’Ancona \& G. Serra (eds), Aristotele e Alessandro di Afrodisia nella tradizione araba, Padova: Il Poligrafo, 2002 (Subsidia mediaevalia patavina, 3), 19-74.

Endress, G., 'Averroes' De caelo: Ibn Rushd's Cosmology in his Commentaries on Aristotle's On the Heavens,' Arabic Sciences and Philosophy, 5 (1995), 949.

Endress, G., 'Mathematics and Philosophy in Medieval Islam,' in: J.P. Hogendijk \& A.I. Sabra (eds), The Enterprise of Science in Islam: New Perspectives, Cambridge (MA), London: MIT Press, 2003 (Dibner Institute studies in the history of science and technology), 121-176.

Endress, G., 'The Circle of al-Kindī. Early Arabic Translations from the Greek and the Rise of Islamic Philosophy', in: G. Endress \& R. Kruk (eds), The Ancient Tradition in Christian and Islamic Hellenism. Studies on the Transmission of Greek Philosophy and Sciences Dedicated to H.-J. Drossaart Lulofs on his Ninetieth Birthday, Leiden: Research School CNws, School of Asian, African, and Amerindian Studies, 1997 (CNws publications, 50), 43-76.

Evans, J., The History and Practice of Ancient Astronomy, New York [etc.]: Oxford University Press, 1998.

Falcon, A., Aristotelianism in the First Century BCE: Xenarchus of Seleucia, Cambridge: Cambridge University Press, 2012.

Fazzo, S., \& H. Wiesner, 'Alexander of Aphrodisias in the Kindī-circle and in al-Kindī's Cosmology', Arabic Sciences and Philosophy, 3 (1993), 119-153.

Ficino, M., Platonic Theology, tr. M.J.B. Allen \& ed. J. Hankins, 6 vols, Cambridge (MA): Harvard University Press, 2001-2006.

Filalteo, L., In IIII. libros Aristotelis De caelo et mundo commentarii, Venezia: Vincentius Valgrisius, 1565.

Finnegan, J., 'Texte arabe du Пвpì voũ d'Alexandre d'Aphrodise', Mélanges de l'Université Saint-Joseph, 33/2 (1956), 157-202. 
Fonseca, P. da, Commentaria in libros Metaphysicorum Aristotelis Stagiritae, 2 vols, Lyon: Giunta, 1597.

Freudenthal, G., 'Averroes' Changing Mind on the Role of the Active Intellect in the Generation of Animal Beings', in: A. Hasnawi (ed.), La lumière de l'intellect. La pensée scientifique et philosophique d'Averroès dans son temps. Actes du $\mathrm{IV}^{\mathrm{e}}$ colloque international de la SIHSPAI (Société internationale d'histoire des sciences et de la philosophie arabes et islamiques). Cordoue, 9-12 décembre 1998, Leuven: Peeters, 2011 (Ancient and Classical Sciences and Philosophy), 319-328.

Freudenthal, G., 'The Medieval Astrologization of Aristotle's Biology: Averroes on the Role of the Celestial Bodies in the Generation of Animate Beings', Arabic Sciences and Philosophy, 12 (2002), 111-137.

Freudenthal, G., 'The Medieval Astrologization of the Aristotelian Cosmos: From Alexander of Aphrodisias to Averroes', Mélanges de l'Université Saint-Joseph, 59 (2006), 29-68.

Gannagé, E., 'Philopon (Jean-). Tradition arabe', in: R. Goulet (ed.), Dictionnaire des Philosophes Antiques, v: De Paccius à Rutilius Rufus; va: De Paccius à Plotin, Paris: Editions du Centre National de la Recherche Scientifique, 2011, 503563.

Gassendi, P., Opuscula philosophica, Lyon: L. Anisson \& J.B. Devenet, 1658.

Gauthier, R.-A., 'Notes sur les débuts (1225-1240) du premier "averroïsme,"' Revue des sciences philosophiques et théologiques, 66 (1982), 321-374.

Genequand, Ch., Alexander of Aphrodisias on the Cosmos, Leiden [etc.]: Brill, 2001 (Islamic philosophy, theology, and science, 44).

Genequand, Ch., Ibn Rushd's Metaphysics: A Translation with Introduction of Ibn Rushd's Commentary on Aristotle's Metaphysics, Book Läm, Leiden [etc.]: Brill, 1984 (Islamic philosophy and theology, 1).

Gensler, M., ed., Kłopotliwa zmiana czyli Waltera Burleya zmagania ze zmiennościa rzeczy, Łódź: Wydawnictwo Uniwersytetu Łódziego, 2007.

Geoffroy, M., 'La Tradition arabe du Пвpì voṽ d'Alexandre d'Aphrodise et les origines de la théorie farabienne des quatre degrés de l'intellect', in: C. D'Ancona \& G. Serra (eds), Aristotele e Alessandro di Afrodisia nella tradizione araba, Padova: Il Poligrafo, 2002 (Subsidia mediaevalia patavina, 3), 191-231.

Geoffroy, M., Sources et origines de la théorie de l'intellect d'Averroès, PhD dissertation: EPHE, Section des sciences religieuses, 2009.

Gilbert, F., 'Cristianesimo, umanesimo e la bolla Apostolici Regiminis del 1513,' Rivista storica italiana, 79 (1967), 976-990.

Gilson, E., Le Thomisme: Introduction au système de Saint Thomas D’Aquin, Paris: Vrin, 1927 (Etudes de philosophie médiévale, 3).

Glanvill, J., The Vanity of Dogmatizing, London: Henry Eversden, 1661. 
Glasner, R., 'Ibn Rushd's Theory of minima naturalia',Arabic Sciences and Philosophy, 11 (2001), 9-26.

Glasner, R., Averroes' Physics. A Turning Point in Medieval Natural Philosophy, Oxford [etc.]: Oxford University Press, 2009.

Glick, Th., et al., Medieval Science, Technology, and Medicine: An Encyclopedia, New York [etc.]: Routledge, 2005.

Goddu, A., 'The Impact of Ockham's Reading of the Physics on the Mertonians and Parisian Terminists', Early Science and Medicine, 6/3 (2001), 204-217.

Goldstein, B.R., 'The Arabic Version of Ptolemy's Planetary Hypotheses', Transactions of the American Philosophical Society. New Series, 54 (1967), 3-55.

Gotthelf, A., 'Aristotle's Conception of Final Causality', in: A. Gotthelf \& J.G. Lennox (eds), Philosophical Issues in Aristotle's Biology, Cambridge: Cambridge University Press, 1987, 204-242.

Goulet, R., \& M. Aouad, 'Alexandros d' Aphrodisias', in: R. Goulet (ed.), Dictionnaire des Philosophes Antiques, I: Abam(m)on à Axiothéa, Paris: Editions du Centre National de la Recherche Scientifique, 1989, 125-139.

Grant, E., A Source Book in Medieval Science, Cambridge (MA): Harvard University Press, 1974 (Source books in the history of the sciences).

Grellard, C., 'Nicholas of Autrecourt's Atomistic Physics', in: C. Grellard \& A. Robert (eds), Atomism in Late Medieval Philosophy and Theology, Leiden [etc.]: Brill, 2009 (Medieval and early modern science, 9), 107-126.

Grene, M., 'Aristotelico-Cartesian Themes in Natural Philosophy: Some SeventeenthCentury Cases', Perspectives on Science, 1 (1993), 66-87.

Guerlac, H., \& M.C. Jacob, 'Bentley, Newton, and Providence: The Boyle Lectures Once More,'Journal of the History of Ideas, 30 (1969), 307-318.

Günz, A., Die Abhandlung Alexanders von Aphrodisias über den Intellekt. Aus handschriftlichen Quellen zum ersten Male herausgegeben und durch die Abhandlung 'Die Nûslehre Alexanders von Aphrodisias und ihr Einfluss auf die arabischjüdische Philosophie des Mittelalters' ergänzt, PhD dissertation: Berlin, 1886.

Gutas, D., 'Averroes on Theophrastus, through Themistius', in: G. Endress \& J.A. Aertsen (eds), Averroes and the Aristotelian Tradition. Sources, Constitution and Reception of the Philosophy of Ibn Rushd (1126-1198). Proceedings of the Fourth Symposium Averroicum (Cologne, 1996), Leiden [etc.]: Brill, 1999 (Islamic philosophy, theology, and science, 31), 63-102.

Gutas, D., 'Avicenna's Marginal Glosses on De Anima and The Greek Commentatorial Tradition,' in: P. Adamson, H. Baltussen \& M.W.F. Stone (eds), Philosophy, Science and Exegesis in Greek, Arabic and Latin Commentaries, London: Institute of Classical Studies, 2004, 77-88.

Gutas, D., 'Philoponus and Avicenna on the Separability of the Intellect: A Case of Orthodox Christian-Muslim Agreement,' The Greek Orthodox Theological 
Review, 31 (1986), 121-129 (repr. in: Greek Philosophers in the Arabic Tradition, Ashgate: Aldershot, 2000 [Variorum collected studies series, 698], art. XI).

Hackett, J.M.G. (ed.), Roger Bacon and the Sciences: Commemorative Essays, Leiden [etc.]: Brill, 1997 (Studien und Texte zur Geistesgeschichte des Mittelalters, 57).

Hasnawi, A., 'Alexandre d'Aphrodise vs. Jean Philopon: notes sur quelques traités d'Alexandre "perdus" en grec, conservés en arabe',Arabic Sciences and Philosophy, 4 (1994), 53-109.

Hasnawi, A., 'La définition du mouvement dans la Physique du Shifã d'Avicenne,' Arabic Sciences and Philosophy, 11 (2001), 103-123.

Hasse, D.N, Latin Averroes Translations of the First Half of the Thirteenth Century, Hildesheim: Olms, 2010.

Hasse, D.N., 'Aufstieg und Niedergang des Averroismus in der Renaissance: Niccolò Tignosi, Agostino, Nifo, Francesco Vimercato', in: J.A. Aertsen \& M. Pickavé (eds), Herbst des Mittelalters? Fragen zur Berwertung des 14. und 15. Jahrhunderts, Berlin [etc.]: De Gruyter, 2004 (Miscellanea Mediaevalia, 31), 447-473.

Hasse, D.N., 'Averroica secta: Notes on the Formation of Averroist Movements in Fourteenth-Century Bologna and Renaissance Italy', in: J.-B. Brenet (ed.), Averroès et les averroïsmes juif et latin. Actes du colloque international, Paris 16-18 juin 2005, Turnhout: Brepols, 2007 (Textes et études du moyen âge, 40), 307-331.

Hasse, D.N., 'The Attraction of Averroism in the Renaissance: Vernia, Achillini, Prassicio,' in: P. Adamson, H. Baltussen \& M.W.F. Stone (eds), Philosophy, Science and Exegesis in Greek, Arabic and Latin Commentaries, London: Institute of Classical Studies, 2004, 131-147.

Heereboord, A., Meletemata philosophica, Nijmegen: A. Hoogenhuysen, 1665.

Hetherington, N.S. (ed.) Encyclopedia of Cosmology: Historical, Philosophical, and Scientific Foundations of Modern Cosmology, New York [etc.]: Garland, 1993 (Garland reference library of the humanities, 1250).

Hissette, R., Enquête sur les 219 articles condamnés à Paris le 7 mars 1277, Leuven: Publications Universitaires - Paris: Vander-Oyez, 1977 (Philosophes médiévaux, 22).

Hooke, R., Micrographia, or Some physiological descriptions of minute bodies made by magnifying glasses: With observations and inquiries thereupon, London: John Martyn, 1665.

Howlett, D.R., et al., Dictionary of Medieval Latin from British Sources, Oxford: Oxford University Press, 1975-.

Hugonnard-Roche, H., 'The Influence of Arabic Astronomy in the Medieval West', in: R. Rashed (ed.), Encyclopedia of the History of Arabic Science, 3 vols, London [etc.]: Routledge, 1996, 1: 284-305. 
Iliffe, R., 'Those “Whose Business It Is to Cavill:” Newton's Anti-Catholicism, in: J.E. Force \& R.H. Popkin (eds), Newton and Religion: Context, Nature, and Influence, Dordrecht: Kluwer, 1999 (International archives of the history of ideas, 161), 97-119.

Janos, D., Method, Structure, and Development in al-Fārābi's Cosmology, Leiden [etc.]: Brill, 2012 (Islamic philosophy, theology, and science, 85).

Javelli, C., Quaestiones naturales super octo libros Physicorum Aristotelis, Lyon: Apud Haeredes Iacobi Iunctae, 1567.

Jedin, H., Conciliorum oecumenicorum decreta, Bologna: Istituto per le Scienze Religiose, 1973.

Jolivet, J., 'L' intellect selon Al-Fārābī. Quelques remarques,' Bulletin d'études orientales, 29 (1997), 251-259.

Jones, H., The Epicurean Tradition, London [etc.]: Routledge, 2001.

Judson, L., 'Heavenly Motion and the Unmoved Mover', in: M.L. Gill \& J.G. Lennox (eds), Self-Motion: From Aristotle to Newton, Princeton (NJ): Princeton University Press, 1994, 155-171.

Kennedy, E.S., 'Alpetragius's Astronomy', Journal for the History of Astronomy, 4 (1973), 134-136.

Kosman, A., 'Aristotle's Prime Mover, in: M.L. Gill \& J.G. Lennox (eds), Self-Motion: From Aristotle to Newton, Princeton (NJ): Princeton University Press, 1994, 135-153.

Koyré, A., From the Closed World to the Infinite Universe, Baltimore: Johns Hopkins University Press, 1968 (The Hideyo Noguchi lectures, 7).

Kraye, J., 'Aristotle's God and the Authenticity of De Mundo: An Early Modern Controversy', Journal of the History of Philosophy, 28 (1990), 339-358.

Kraye, J., 'Daniel Heinsius and the Author of De Mundo', in: A.C. Dionisotti, A. Grafton \& J. Kraye (eds), The Uses of Greek and Latin. Historical Essays, London: The Warburg Institute, 1988 (Warburg Institutes surveys and texts, 16), 171-197.

Kren, C., 'A Medieval Objection to "Ptolemy,"' The British Journal for the History of Science, 4 (1969), 378-393.

Kren, C., 'Homocentric Astronomy in the Latin West: The De reprobatione ecentricorum et epiciclorum of Henry of Hesse', Isis, 59 (1968), 269-281.

Kubrin, D., 'Newton and the Cyclical Cosmos: Providence and the Mechanical Philosophy', Journal of the History of Ideas, 28 (1967), 325-346.

Kuhn, H.C., 'Cesare Cremonini: Volti e maschere di un filosofo scomodo per tre secoli e mezzo', in: E. Riondato \& A. Poppi (eds), Cesare Cremonini: Aspetti del pensiero e scritti, Padova: Accademia galileiana di scienze, lettere ed arti in Padova, 2000 (Historia, 1), 153-168.

Kupreeva, I., Alexander of Aphrodisias on Soul as Form (De anima 1-26 Bruns), PhD dissertation: University of Toronto, 1999. 
Kusukawa, S., The Transformation of Natural Philosophy: The Case of Philip Melanchthon, Cambridge: Cambridge University Press, 1995 (Ideas in context, 34).

Lagarde, B., 'Le De differentiis de Pléthon d'après l' autographe de la marcienne', Byzantion, 43 (1973), 312-343.

Lamy, B., Entretiens sur les sciences, dans lesquels on apprend comment l'on doit étudier les sciences, et s'en servir pour se faire l'esprit juste, et le coeur droit, ed. F. Girbal \& P. Clair, Paris: Presses Universitaires de France, 1966 (Le mouvement des idées au XVII ${ }^{e}$ siècle, 5 ).

Langermann, T., Ibn al-Haytham's On the Configuration of the World, New York [etc.]: Garland, 1990.

Lay, J., 'L'Abrégé de l'Almageste: Un inédit d'Averroès en version hébraïque,' Arabic Sciences and Philosophy, 6 (1996), 23-61.

Leibniz, G.W., Sämtliche Schriften und Briefe, 6. Reihe: Philosophische Schriften, Berlin: Akademie-Verlag, 1923-, 6/4a.

Lettinck, P., Aristotle's Physics and its Reception in the Arabic World. With an Edition of the Unpublished Parts of Ibn Bäjja's Commentary on the Physics, Leiden [etc.]: Brill, 1994 (Aristoteles semitico-latinus, 7).

Liceti, F., De pietate Aristotelis erga deum \& homines libri duo, Udine: Schiratti, 1645.

Liddell, H.G., R. Scott \& H.S. Jones, A Greek-English Lexicon, Oxford: Clarendon Press, ${ }^{9} 1940$.

Ligorio, P., Libro di diversi terremoti, ed. E. Guidoboni, Roma: De Luca Editori d'Arte, 2005 (Libri delle antichità, 28).

Litt, Th., Les corps célestes dans l'univers de Saint Thomas d'Aquin, Leuven: Publications Universitaires - Paris: Béatrice-Nauwelaerts, 1963 (Philosophes médiévaux, 7).

Livesey, S.J., 'The Oxford Calculatores, Quantification of Qualities, and Aristotle's Prohibition of Metabasis', Vivarium, 24 (1986), 50-69.

Livesey, S.J., 'William of Ockham, the Subalternate Sciences, and Aristotle's Theory of metabasis', British Journal for the History of Science, 18 (1985), 127-145.

Lloyd, G.E.R., 'Metaphysics $\Lambda$ 8', in: M. Frede \& D. Charles (eds), Aristotle's Metaphysics Lambda. Symposium Aristotelicum, Oxford: Clarendon Press, 200o, 245-274.

Lohr, Ch., Latin Aristotle Commentaries, II: Renaissance Authors, Firenze: Olschki, 1988 (Corpus philosophorum medii aevi. Subsidia, 6).

Lukács, L. (ed.), Monumenta paedagogica Societatis Iesu, 5: Ratio atque institutio studiorum Societatis Iesu (1586, 1591, 1599), nova editio penitus retracta, Roma: Institutum Historicum Societatis Jesu, 1986 (Monumenta historica Societatis Iesu, 129).

Mahdi, M., 'Alfarabi against Philoponus', Journal of Near Eastern Studies, 26 (1967), 233-26o. 
Mahdi, M., 'The Arabic Text of Alfarabi's Against John the Grammarian,' in: S.A. Hanna (ed.), Medieval and Middle Eastern Studies in Honor of Aziz Suryal Atiya, Leiden [etc.]: Brill, 1972, 268-284.

Maier, A., Die Vorläufer Galileis im 14. Jahrhundert (Studien zur Naturphilosophie der Spätscholastik, 1), Roma: Edizioni di storia e letteratura, ${ }^{2} 1966$ (Storia e letteratura, 22).

Maier, A., Zwischen Philosophie und Mechanik (Studien zur Naturphilosophie der Spätscholastik, 5), Roma: Edizioni di storia e letteratura, 1958 (Storia e letteratura, 69).

Malebranche, N., The Search after Truth [Recherche de la vérité], tr. Th.M. Lennon \& P.J. Olscamp, Cambridge: Cambridge University Press, 1997 (Cambridge texts in the history of philosophy).

Mancha, J.L., 'Ibn al-Haytham's Homocentric Epicycles in Latin Astronomical Texts of the $\mathrm{XIV}^{\text {th }}$ and $\mathrm{XV}^{\text {th }}$ Centuries', in: J.L. Mancha, Studies in Medieval Astronomy and Optics, Aldershot: Ashgate, 2006 (Variorum collected studies series, 852), art. VIII.

Maróth, M., 'The Ten Intellects Cosmology and its Origin', The Arabist, 13-14 (1995), 103-113.

Martin, A., Averroès: Grand commentaire de la Métaphysique d'Aristote (Tafsīr mä ba'd at-tabī'a): livre Lam-Lambda, Paris: Les Belles Lettres, 1984 (Bibliothèque de la Faculté de Philosophie et Lettres de l'Université de Liège, 234).

Martin, C., 'The Ends of Weather: Teleology in Renaissance Meteorology', Journal of the History of Philosophy, 48 (2010), 259-282.

Mazzoni, J., In universam Platonis et Aristotelis philosophiam praeludia, sive de comparatione Platonis et Aristotelis, ed. S. Matteoli, Napoli: M. D’Auria, 2010 (Storie e testi, 19).

Mersenne, M., La vérité des sciences. Contre les sceptiques ou pyrrhoniens, Paris: Toussaint du Bray, 1625 (repr. Stuttgart-Bad Cannstatt: Frommann 1969).

Mersenne, M., Quaestiones celeberrimae in Genesim, cum accurata textus explicatione, Paris: Sebastien Cramoisy, 1623.

Methuen, C., 'Special Providence and Sixteenth-Century Astronomical Observation: Some Preliminary Observations, Early Science and Medicine, 4 (1999), 99-113.

Michot, J., 'La réponse d'Avicenne à Bahmanyār et al-Kirmānī. Présentation, traduction critique et lexique arabe-français de la Mubāhatha III', Le Muséon, 110 (1997), 143-221.

Millás Vallicrosa, J.M., Las traducciones orientales en los manuscritos de la Biblioteca Catedral de Toledo, Madrid: Consejo superior de investigaciones cientìficas, 1942.

Moraux, P., 'Le De anima dans la tradition grecque. Quelques aspects de l'interprétation du traité, de Théophraste à Thémistius', in: G.E.R. Lloyd \& G.E.L. Owen 
(eds), Aristotle on Mind and the Senses. Proceedings of the seventh symposium Aristotelicum, Cambridge: Cambridge University Press, 1978, 281-324.

Moraux, P., Alexandre d'Aphrodise exégète de la noétique d'Aristote, Liège: Faculté de Philosophie - Paris: Droz, 1942.

Moraux, P., Der Aristotelismus bei den Griechen: von Andronikos bis Alexander von Aphrodisias, 3 vols, Berlin [etc.]: De Gruyter, 1973-2001 (Peripatoi, 5-7).

Murdoch, J.E., 'Beyond Aristotle: Indivisibles and Infinite Divisibility in the Later Middle Ages', in: C. Grellard \& A. Robert (eds), Atomism in Late Medieval Philosophy and Theology, Leiden [etc.]: Brill, 2009 (Medieval and early modern science, 9), 15-38.

Murdoch, J.E., 'Superposition, Congruence and Continuity in the Middle Ages', in: I.B. Cohen \& R. Taton (eds), Mélanges Alexandre Koyré, 1: L'aventure de la science, Paris: Hermann, 1964 (Histoire de la pensée, 12), 416-441.

Murdoch, J.E., 'The Medieval and Renaissance Tradition of minima naturalia', in: C. Lüthy, J.E. Murdoch \& W.R. Newman (eds), Late Medieval and Early Modern Corpuscular Matter Theories, Leiden [etc.]: Brill, 2001 (Medieval and early modern science, 1 ), 91-131.

Murdoch, J.E., 'Thomas Bradwardine: Mathematics and Continuity in the Fourteenth Century'. in: E. Grant \& J.E. Murdoch (eds), Mathematics and Its Applications to Science and Natural Philosophy in the Middle Ages. Essays in Honor of Marshall Clagett, Cambridge: Cambridge University Press, 1987, 103-137.

Nardi, B., 'La fine dell'averroismo', in: Id., Saggi sull'aristotelismo padovano dal secolo XIV al XV, Firenze: Sansoni, 1958 (Studi sulla tradizione Aristotelica nel Veneto, 1), 443-455.

Newton, I., Drafts on the History of the Church (section 5), Ms Jerusalem, National Library of Israel, Yahuda 15.5, URL: <http://www.newtonproject.sussex.ac.uk/ view/texts/diplomatic/THEMoo222>.

Newton, I., The Principia: Mathematical Principles of Natural Philosophy, tr. I.B. Cohen \& A. Whitman, Berkeley (CA): University of California Press, 1999.

Nifo, A., Expositiones in Aristotelis libros Metaphysices, Venezia: Hieronymus Scotus, 1559 (repr. Frankfurt am Main: Minerva, 1967).

Nifo, A., In XII Metaphysices Aristotelis et Averrois volumen, Venezia: Octavianus Scotus, 1518.

North, J.D., The Fontana History of Astronomy and Cosmology, London: Fontana Press, 1994 (Fontana history of science).

Osler, M.J., 'Providence and Divine Will in Gassendi's Views on Scientific Knowledge,' Journal of the History of Ideas, 44 (1983), 549-560.

Panti, C., Moti, virtù e motori celesti nella cosmologia di Roberto Grossatesta, Firenze: Edizioni del Galluzzo, 2001 (Testi e studi per il Corpus philosophorum medii aevi, 16). 
Parker, S., Disputationes de deo, et providentia divina, London: M. Clark, 1678.

Patrizi, F., Apologia contra calumnias Theodori Angelutii, Ferrara: Dominicus Mamarellus, 1584.

Patrizi, F., Nova de universis philosophia, Ferrara: Benedictus Mammarellus, 1591.

Patrizi, F., Nova de universis philosophia: Materiali per un'edizione emendata, ed. A.L. Puliafito Bleuel, Firenze: Olschki, 1993.

Piccolomini, F., Librorum ad scientiam de natura attinentium pars secunda, Venezia: De Franciscis, 1600.

Pluta, O., 'Averroes als Vermittler der Gedanken des Alexander von Aphrodisias,' in: F. Niewöhner \& L. Sturlese (eds), Averroismus im Mittelalter und in der Renaissance, Zürich: Spur Verlag, 1994, 201-221.

Pluta, O., 'How Matter Becomes Mind: Late-Medieval Theories of Emergence, in: H. Lagerlund (ed.), Forming the mind. Essays on the Internal Senses and the Mind/Body Problem from Avicenna to the Medical Enlightenment, Dordrecht: Springer, 2007 (Studies in the history of philosophy of mind, 5), 149167.

Podkoński, R., 'Al-Ghazali's "Metaphysics" as a Source of Anti-atomistic Proofs in John Duns Scotus's Sentences Commentary', in: A. Speer \& L. Wegener (eds), Wissen über Grenzen. Arabisches Wissen und lateinisches Mittelalter, Berlin [etc.]: De Gruyter, 2006 (Miscellanea Mediaevalia, 33), 612-625.

Pomponazzi, P., Libri quinque de fato, de libero arbitrio et de praedestinatione, ed. R. Lemay, Lucani: Thesaurus mundi, 1957 (Thesaurus mundi, 8).

Possevino, A., Bibliotheca selecta de ratione studiorum in Historia, in Disciplinis, in salute omnium procuranda, 2 vols, Roma: Domenico Basa, 1593.

Postel, G., Eversio falsorum Aristotelis dogmatum, Paris: Sebastianus Nivellius, 1552.

Postel, G., Liber de causis, Paris: Sébastien Nivelle, 1552.

Preus, R.D., The Theology of Post-Reformation Lutheranism, 2 vols, St. Louis: Concordia Publishing House, 1970-1972.

Prinz, O., et al., Mittellateinisches Wörterbuch bis zum ausgehenden 13. Jahrhundert, München: Bayerische Akademie der Wissenschaften, 1967-.

Puig Montada, J., 'Averroes and Aquinas on Physics virı.1. A Search for the Roots of Dissent,' in: S. Knuuttila, R. Työrinoja \& S. Ebbesen (eds), Knowledge and the Sciences in Medieval Philosophy. Proceedings of the Eighth International Congress of Medieval Philosophy (s.I.E.P.M.), Helsinki, 24-29 August 1987, Helsinki: Luther-Agricola Society, 1990, 307-313.

Puig Montada, J., 'Averroes y el problema de la eternidad del movimiento', Ciudad de dios, 212 (1999), 231-244.

Puig Montada, J., 'Les stades de la philosophie naturelle d'Averroès', Arabic Sciences and Philosophy, 7 (1997), 115-137.

Puig Montada, J., 'Zur Bewegungsdefinition im viı. Buch der Physik', in: G. Endress 
\& J.A. Aertsen (eds), Averroes and the Aristotelian Tradition. Sources, Constitution and Reception of the Philosophy of Ibn Rushd (1126-1198). Proceedings of the Fourth Symposium Averroicum (Cologne, 1996), Leiden [etc.]: Brill, 1999 (Islamic philosophy, theology, and science, 31), 145-159.

R.B. [Richard Bostocke], Auncient Phisicke, London: Walley, 1585.

Ragland, C.P., 'Descartes on Divine Providence and Human Freedom,' Archiv für Geschichte der Philosophie, 87 (2005), 159-188.

Rashed, M. (ed. et tr.), Aristote: De la génération et la corruption, Paris: Les Belles Lettres, 2005.

Rashed, M., 'Al-Fārābī's Lost Treatise On Changing Beings and the Possibility of a Demonstration of the Eternity of the World', Arabic Sciences and Philosophy, 18 (2008), 19-58.

Rashed, M., 'Nouveaux fragments anti-procliens de Philopon en version arabe et le problème des origines de la théorie de l' 'instauration' (hudūth)', in: G. Federici Vescovini \& A. Hasnawi (eds), Circolazione dei saperi nel Mediterraneo. Filosofia e scienze (secoli IX-XVI), Firenze: Edizioni Cadmo, 2013, 323-36o.

Rashed, M., Alexandre d'Aphrodise: Commentaire perdu à la Physique d'Aristote (Livres IV-VIII). Les scholies byzantines. Edition, traduction et commentaire, Berlin [etc.]: De Gruyter, 2011 (Commentaria in Aristotelem Graeca et Byzantina. Quellen und Studien, 1).

Rashed, M., Essentialisme. Alexandre d'Aphrodise entre logique, physique et cosmologie, Berlin [etc.]: De Gruyter, 2007 (Commentaria in Aristotelem Graeca et Byzantina, 2).

Raynaud, T., Erotemata de malis ac bonis libris, Lyon: J.A. Huguetan \& M.A. Ravaud, 1653.

Ross, W.D., Aristotle's Physics. A Revised Text with Introduction and Commentary, Oxford: Clarendon Press, 1960 ( $\left.{ }^{1} 1936\right)$.

Ruland, H.-J., Die arabischen Fassungen von zwei Schriften des Alexander von Aphrodisias über die Vorsehung und über das liberum arbitrium, PhD dissertation: Universität Saarbrücken, 1976.

Sabra, A.I., 'Configuring the Universe: Aporetic, Problem Solving, and Kinematic Modeling as Themes of Arabic Astronomy', Perspectives of Science, 6 (1998), 288-330 (repr. in: P.E. Pormann [ed.], Islamic Medical and Scientific Tradition: Critical Concepts in Islamic Studies, London [etc.]: Routledge, 2011, 3: 95-134).

Sabra, A.I., 'Ibn al-Haytham,' in: C.C. Gillispie (ed.), Dictionary of Scientific Biography, New York: Charles Scribner's Sons, 1970-1980, 6: 189-210.

Sabra, A.I., 'The Andalusian Revolt Against Ptolemaic Astronomy: Averroes and al-Bițrūjì', in: E. Mendelsohn (ed.), Transformation and Tradition in the Sciences. Essays in Honor of I. Bernard Cohen, Cambridge (MA): Cambridge University 
Press, 1984, 133-153 (repr. in A.I. Sabra, Optics, Astronomy and Logic: Studies in Arabic Science and Philosophy, Aldershot: Ashgate, 1994 [Variorum collected studies series, 444], art. Xv).

Sabra, A.I., 'The Simple Ontology of Kalam Atomism: An Outline', Early Science and Medicine, 14 (2009), 68-78.

Samsó, J., 'On al-Bitruji and the Hay’a Tradition in al-Andalus', in: J. Samsó, Islamic Astronomy and Medieval Spain, Aldershot: Ashgate, 1994 (Variorum collected studies series, 428), art. XII.

Schmitt, Ch.B., 'Renaissance Averroism Studied through the Venetian Editions of Aristotle-Averroes (with Particular Reference to the Giunta Edition of 15501552), in: L'Averroismo in Italia. Convegno internazionale, Roma, 18-20 aprile 1977, Roma: Accademia Nazionale dei Lincei, 1979, 121-142 (repr in: The Aristotelian Tradition and Renaissance Universities, London: Variorum Reprints, 1984 [Variorum collected studies series, 203], art. VIII).

Schroeder, F.M., 'The Potential or Material Intellect and the Authorship of the De intellectu. A Reply to B.C. Bazán', Symbolae Osloenses, 57 (1982), 115-125.

Schroeder, F.M., 'The Provenance of the De intellectu Attributed to Alexander of Aphrodisias,'Documenti e studi sulla tradizione filosofica medievale, 7 (1997), 105-120.

Schroeder, F.M., \& R.B. Todd, 'The De intellectu Revisited,' Laval théologique et philosophique, 64/3 (2008), 663-680.

Schroeder, F.M., \& R.B. Todd, Two Greek Aristotelian Commentators on the Intellect. The De intellectu Attributed to Alexander of Aphrodisias and Themistius' Paraphrase of Aristotle De anima 3.4-8, Toronto: Pontifical Institute of Mediaeval Studies, 1990 (Mediaeval sources in translation, 33).

Sebti, M., 'The Ontological link between Body and Soul in Bahmanyār's Kitāb al-Tahṣil', The Muslim World, 102 (2012), 525-540.

Shank, M., 'Setting up Copernicus? Astronomy and Natural Philosophy in Giambattista Capuano da Manfredonia's Expositio on the Sphere', Early Science and Medicine, 14 (2009), 290-315.

Sharples, R.W., 'Alexander of Aphrodisias: Scholasticism and Innovation,' in: W. Haase (ed.), Aufstieg und Niedergang der römischen Welt, II: Principat; 36/2: Philosophie (Platonismus [Forts.]; Aristotelismus), Berlin [etc.]: De Gruyter, 1987, 11761243.

Sharples, R.W., 'On Body, Soul and Generation in Alexander of Aphrodisias', Apeiron, 27/2 (1994), 163-170.

Sirmond, A., De immortalitate animae demonstratio physica \& Aristotelica, Paris: Michel Soly, 1635.

Sorabji, R., Time, Creation, and the Continuum. Theories in Antiquity and the Early Middle Ages, London [etc.]: Cornell University Press, 1983. 
Steel, C., \& G. Guldentops, 'An Unknown Treatise of Averroes against the Avicennians on the First Cause. Edition and Translation,'Recherches de Théologie et Philosophie médiévales, 64/1 (1997), 86-135.

Sylla, E.D., 'Aristotelian Commentaries and Scientific Change: The Parisian Nominalists on the Cause of the Natural Motion of Inanimate Bodies,' Vivarium, 31 (1993), 37-83.

Sylla, E.D., 'Astronomy at Cracow University in the late Fifteenth Century: Albert of Brudzewo and John of Glogów', in: E. Jung (ed.), What is New in the New Universities? Learning in Central Europe in Later Middle Ages (1348-150o). Proceedings of the XVIII ${ }^{\text {th }}$ colloquium of the SIEPM, Łódź, 8-10 September 2011, forthcoming.

Sylla, E.D., 'Disputationes Collativae: Walter Burley's Tractatus Primus and Gregory of Rimini's Lectura super primum et secundum Sententiarum,' Documenti e studi sulla tradizione filosofica medievale, 22 (2011), 383-464.

Sylla, E.D., 'God and the Continuum in the Later Middle Ages: The Relations of Philosophy to Theology, Logic, and Mathematics', in: J.A. Aertsen \& A. Speer (eds), Was ist Philosophie im Mittelalter? Akten des x. Internationalen Kongresses für Mittelalterliche Philosophie der Société Internationale pour l'Etude de la Philosophie Médiévale, 25. bis 30. August 1997 in Erfurt, Berlin [etc.]: De Gruyter, 1998 (Miscellanea Mediaevalia, 26), 791-797.

Sylla, E.D., 'John Buridan and Critical Realism,'Early Science and Medicine, 14 (2009), 211-247.

Sylla, E.D., 'Mathematical Physics and Imagination in the Work of the Oxford Calculators: Roger Swineshead's On Natural Motions', in: E. Grant \& J.E. Murdoch (eds), Mathematics and Its Applications to Science and Natural Philosophy in the Middle Ages. Essays in Honor of Marshall Clagett, Cambridge: Cambridge University Press, 1987, 69-101.

Sylla, E.D., 'The Oxford Calculators' Middle Degree Theorem in Context,' Early Science and Medicine, 15 (2010), 338-370.

Sylla, E.D., 'Thomas Bradwardine's De continuo and the Structure of FourteenthCentury Learning,' in: E.D. Sylla \& M. McVaugh (eds), Texts and Contexts in Ancient and Medieval Science. Studies on the Occasion of John E. Murdoch's Seventieth Birthday, Leiden [etc.]: Brill, 1997 (Brill's studies in intellectual history, 78), $48-86$.

Sylla, E.D., 'Walter Burley's Practice as a Commentator on Aristotle's Physics', Medioevo, 27 (2002), 301-372.

Taub, L.C., Ptolemy's Universe: The Natural Philosophical and Ethical Foundations of Ptolemy's Astronomy, Chicago [etc.]: Open Court, 1993.

Taurellus, N., Alpes caesae. Hoc est, Andr. Caesalpini Itali, monstrosa \& superba dogmata, discussa \& excussa, Frankfurt: Palthenius, 1597. 
Telesio, B., De rerum natura iuxta propria principia, ed. L. de Franco, 2 vols, Cosenza: Casa del Libro, 1965.

Théry, G., Autour du décret de 1210, II: Alexandre d'Aphrodise. Aperçu sur l'influence de sa noétique, Kain: Le Saulchoir, 1926 (Bibliothèque thomiste, 7).

Thijssen, J.M.M.H., 'Buridan on Mathematics,' Vivarium, 21 (1985), 55-78.

Toletus, F., Commentaria una cum quaestionibus in octo libros Aristotelis De physica auscultatione, Venezia: Apud Junctas, 1580.

Trifogli, C., 'Change, Time, and Place' in: R. Pasnau \& C. van Dyke (eds), The Cambridge History of Medieval Philosophy, Cambridge: Cambridge University Press, 2010, 1: 267-278.

Trifogli, C., 'Continuità e discontinuità delle grandezze fisiche in Egidio Romano,' Nuncius, 5/2 (1990), 53-73.

Trifogli, C., 'Due questioni sul movimento nel commento alla Physica di Thomas Wylton', Medioevo, 21 (1995), 31-73.

Trifogli, C., 'Giles of Rome on the Instant of Change', Synthese, 96 (1993), 93114.

Trifogli, C., 'Motion and Time', in: A.D. Conti (ed.), A Companion to Walter Burley, Leiden [etc.]: Brill, 2013 (Brill's companions to the Christian tradition, 41), 272-284.

Trifogli, C., 'Thomas Wylton on Motion', Archiv für Geschichte der Philosophie, 77 (1995), 135-154.

Trifogli, C., Liber Quartus Physicorum Aristotelis: Repertorio delle Questioni. Commenti inglese ca. 1250-1270, Firenze: SISMEL - Edizioni del Galluzzo, 2007 (Corpus philosophorum medii aevi. Subsidia, 16).

Trifogli, C., Liber Tertius Physicorum Aristotelis: Repertorio delle Questioni. Commenti inglese ca. 1250-1270, Firenze: SISMEL - Edizioni del Galluzzo, 2004 (Corpus philosophorum medii aevi. Subsidia, 13).

Trifogli, C., Oxford Physics in the Thirteenth Century (ca. 1250-1270): Motion, Infinity, Place and Time, Leiden [etc.]: Brill, 2000 (Studien und Texte zur Geistesgeschichte des Mittelalters, 72).

Twetten, D., 'Averroes on the Prime Mover Proved in the Physics', Viator, 26 (1995), 107-134.

Twetten, D., 'Averroes' Prime Mover Argument', in: J.-B. Brenet (ed.), Averroès et les averroïsmes juif et latin. Actes du colloque international, Paris 16-18 juin 2005, Turnhout: Brepols, 2007 (Textes et études du moyen âge, 40), 9-75.

Ullmann, M., Wörterbuch der Klassischen Arabischen Sprache, II.3, Wiesbaden: Otto Harrassowitz, 2000.

Uña Juarez, A., La filosofia del siglo XIV. Contexto Cultural de Walter Burley, El Escorial (Madrid): Real Monasterio, 1978 (Biblioteca La Ciudad de Dios, 1. Libros, 26). 
Vallat, Ph., 'Onto-noétique. L' intellect et les intellects chez Fārābī', in: Al-Fārābī, Epître sur l'intellect (Risāla fì l-'aql). Introduction, traduction, et commentaire de Ph. Vallat, Paris: Les Belles Lettres, 2012.

Van Steenberghen, F., Maître Siger de Brabant, Leuven: Publications Universitaires, 1977 (Philosophes médiévaux, 21).

Verbeek, Th., Descartes and the Dutch: Early Reactions to Cartesian Philosophy, 1637-1650, Carbondale (IL): Southern Illinois University Press, 1992.

Vossius, G.J., De theologia gentili, et physiologia Christiana; sive De origine ac progressu idololatriae; deque naturae mirandis, quibus homo adducitur ad deum, libri ix, Amsterdam: Joan Blaeu, 1668.

Vuillemin-Diem, G., 'Praefatio: Wilhelm von Moerbekes Übersetzung der Aristotelischen Metaphysik,' in: Aristoteles Latinus, Metaphysica lib. I-XIV: Recensio et Translatio Guillelmi de Moerbeka, ed. G. Vuillemin-Diem, 1, Leiden [etc.]: Brill, 1995 (Aristoteles latinus, 25.3/1).

Webster, J., Academiarum examen, or, the Examination of Academies, London: Giles Calvert, 1654 .

Weisheipl, J.A., 'The Celestial Movers in Medieval Physics', in: J.A. Weisheipl (ed.), The Dignity of Science. Studies in the Philosophy of Science presented to W.H. Kane, Washington (DC): The Thomist Press, 1961, 150-190.

Weisheipl, J.A., 'The Spector of motor coniunctus in Medieval Physics,' in: A. Maierù \& A. Paravicini Bagliani (eds), Studi sul XIV secolo in memoria di Anneliese Maier, Roma: Edizioni di Storia e Letteratura, 1981 (Storia e letteratura, 151), 81-104.

Wolfson, H.A., 'The Problem of the Souls of the Spheres from the Byzantine Commentaries on Aristotle through the Arabs and St. Thomas to Kepler', in: H.A. Wolfson, Studies in the History of Philosophy and Religion, Cambridge (мA) [etc.]: Harvard University Press, 1979, 1: 22-59.

Wood, R., 'Walter Burley's Physics Commentaries', Franciscan Studies, 44 (1984), 275-327.

Woodhouse, C.M., George Gemistos Plethon: The Last of the Hellenes, Oxford: Clarendon Press, 1986.

Zonta, M., 'La tradizione giudeo-araba ed ebraica del intellectu di Alessandro di Afrodisia e il testo originale del Commento di Averroè,' Annali di Ca' Foscari, 40/3 (2001) (Serie orientale, 32), 17-35. 
2015167 [Bakker] 011-Indices-print [date 1510191536 : version 1509110900] page 238

Reprint from Averroes' Natural Philosophy and its Reception in the Latin West - ISBN 9789462700468 - (C) Leuven University Press, 2015 


\section{INDEX CODICUM MANU SCRIPTORUM}

Ms Basel, Universitätsbibliothek, F.V.12 182n98, 183n98

Ms Cambridge, Gonville and Caius College Library, $367 \quad 92$ Ms Cambridge, Gonville and Caius College Library, 448 (409) $182 n 98$ Ms Cambridge, Gonville and Caius College Library, 51393 Ms Cambridge, Peterhouse Library, 15792 Ms Città del Vaticano, Biblioteca Apostolica Vaticana, Borgh. 11492 Ms Erfurt, Universitätsbibliothek, Dep. Erf., CA F. 34992 MS Jerusalem, National Library of Israel, Yahuda 15.5 211n91 MS Kassel, Gesamthochschul-, Landes- und Murhardsche Bibliothek, Phys. $2^{\circ} 11$ 92 MS Leipzig, Universitätsbibliothek, 138692 MS London, British Library, Burney 35891 MS Montpellier, Bibliothèque interuniversitaire, Sect. de médicine, H. 29393 MS Oxford, Merton College Library, 27292 Ms Oxford, New College Library, 28592 MS Padova, Biblioteca Antoniana, XVII 38092 MS Paris, Bibliothèque Mazarine, $3493 \quad 92$ MS Paris, Bibliothèque Nationale de France, lat. 1469892 MS Paris, Bibliothèque Nationale de France, lat. 1629792 MS Siena, Biblioteca Comunale degli Intronati, L.III.21 91 MS Todi, Biblioteca Comunale, $23 \quad$ 107n63 
2015167 [Bakker] 011-Indices-print [date 1510191536 : version 1509110900] page 240

Reprint from Averroes' Natural Philosophy and its Reception in the Latin West - ISBN 9789462700468 - (C) Leuven University Press, 2015 


\section{INDEX NOMINUM}

All names mentioned in the book, with the exception of Averroes, are included in this index. Medieval authors (before ca. 1500) are alphabetically listed according to their first names, modern authors according to their last names.

Abū Bišr Mattā 74, 74n23

Accattino, P. 4.2n17, 44n24, 45n27, 46n27, 47n3o, 47n32, 50n37, 51040

Achillini, A. 88, 205, 205n54

Adam, Ch. $196 \mathrm{n} 15$

Adamson, P. 45n25, 196n14

Aertsen, J.A. 1n2, 38n5, 150n28, 196n14

Aho, T. $146 \mathrm{n} 17$

Aiello, A. $115 \mathrm{n} 8 \mathrm{o}$

Al-Ahwānī, F. $\quad 55 \mathrm{n} 46$

Al-'Alawī, Ğ. $\quad$ 2, 2n3, 18n 48

Al-Bițrūğì $\quad x, 71,72,72 n 8,73-75,77$, $77 n 35,83,86$

Al-Fargānī 82

Al-Fārābī VıIII, 1-3, 3n5, 4, 5, 7, 8, $12,13,16,17,17 \mathrm{n} 45,18,18 \mathrm{n} 48,19$, 19n49, 20, 2on5o, 21-23, 23n 56, 24, 25, 28, 29, 29n67, 29n69, 30, 31n 71 , $32,33,35,37,157,157 \mathrm{n} 49,167 \mathrm{n} 74$, $171 \mathrm{n} 8 \mathrm{o}$

Al-Ǵazālī 6o, 151, 151n33, 184, 184 n10o

Al-Kindī 4

Albert of Brudzewo 88

Albert the Great XI, 52n41, 53n42, 76, 77, 77n35, 77n36, 78, 86, 87, 91, 101 101n $45,102,102 \mathrm{n} 47,102 \mathrm{n} 48,103$, 152, 157n52, 206

Alexander of Aphrodisias VIII, IX, 2 $3 \mathrm{n} 5,12,13,13 \mathrm{n} 26,13 \mathrm{n} 28,13 \mathrm{n} 29,14$, 14n3o, 15, 15n $37,16,18,19,19 \mathrm{n} 49$,
29, 29n67, 32n $73,33,37,4$ o, 4on12, 41, 41n14, 41n15, 41n17, 42, 42n19, $42 \mathrm{n} 2 \mathrm{O}, 42 \mathrm{n} 21,43,43 \mathrm{n} 23,44,44 \mathrm{n} 23$, 44n24, 45, 45n25, 46, 46n27, 47, 47n3o, 47n31, 47n32, 48, 48n33, 49n35, 49n36, 5o, 5on 37, 5on38, 51, 51n $4 \mathrm{O}, 52,53,53 \mathrm{n} 42,54,55,55 \mathrm{n} 45$, $55 \mathrm{n} 48,56,57,59-62,64,65,65 \mathrm{n} 71$, $65 \mathrm{n} 74,66,66 \mathrm{n} 75,67,148,15 \mathrm{O}, 197$, 197n21

Allen, M.J.B. $\quad$ 2oon29, 2oon3o

Ambrosius 203

Anaxagoras $143,148,15 \mathrm{O}, 154,154 \mathrm{n} 43$, $165,165 \mathrm{n} 67$

Aouad, M. 42n18

Aris, M.-A. 119n91, 161n59

Aristotle VII-XII, XIV, 1-3, 5, 5n11, 6n12, 7, 8, 13, 14, 14n31, 14n32, 15n36, 2o, 2on 5 O, 22, 23, 23n $56,24,25$, 25n $57,25 \mathrm{n} 58,25 \mathrm{n} 59,26,27 \mathrm{n} 62$, 27n64, 28, 28n65, 28n66, 30, 31, 31n71, 31n73, 32, 32n 73, 32n 74, 3340, 4on11, 44, 46-49, 49n35, 49n36, $52,53,57,59,62,62 n 61,63,65,66$, $66 \mathrm{n} 76,67 \mathrm{n} 76,69,70,73,74,77,78$, $81,84,85 n 63,89,89 n 1,89 n 2,89 n 3$, 9o, 9on4, 9on5, 9on6, 91, 93, 93n1o, 93n11, 93n12, 94, 94n13, 94n14, 94n15, 94n16, 94n17, 94n18, 95, 95n19, 95n2o, 97, 99, 100, 102, 103, 103n $51,105,106,106 \mathrm{n} 60,108 \mathrm{n} 64$, $110 n 71,111,116 \mathrm{n} 82,118 \mathrm{n} 89$, 119, 119n91, 120, 121n95, 122, 123 , 
Aristotle (Cont.) 123n101, 123n1o3, $124,127,128,128 \mathrm{n} 4,128 \mathrm{n} 5,129 \mathrm{n} 6$, 13o, 135, 136n22, 137, 137n25, 138n26, 139, 141, 141n2, 142, 143, 144n14, 146-151, 153, 154, 154n41, 155n44, $156,156 \mathrm{n} 47,157-165,165 \mathrm{n} 67,166$, 166n68, 166n69, 167, 168, 168n75, 169,169n 76 , 17on $77,171,171 \mathrm{n} 78$, 171n 8 o, 172, 175, 175n $86,176 \mathrm{n} 86,177$, 177n89, 178n9o, 179, 179n91, 179n92, 18o, 18on94, 181, 182n97, 182n98, 183, 183n98, 183n99, 184, 184n1oo, 185, 185n103, 185n104, 186, 187, 187n1o7, 188, 188n11o, 189, 189n113, 189n114, 19o, 19on115, 19on116, 191, 191n116, 192, 193, 193n4, 194, 195, 197, 197n21, 198-200, 2oon29, 2oon31, 201, 2o1n33, 201n35, 201n37, 201n38, 202, 202n38, 202n 43, 203, 203n 45, 203n46, 204, 204n5o, 205, 205n56, 206, 206n6o, 206n62, 207, 207n7o, 208, 209, 209n78, 210, 210n84, 211

Aristotle of Mytilene $\quad 47,48$

Armogathe, J.R. 207n69

Arnobius 203

Arnzen, R. $\quad 64 \mathrm{n} 70,65 \mathrm{n} 73,72 \mathrm{n} 9,72 \mathrm{n} 12$, 73n14, 73n15, 101n43

Augustine 203

Avicenna $\mathrm{X}, 12,2 \mathrm{O}, 20 \mathrm{n}_{50} \mathrm{O}, 21,44$, 45n26, 95, 96, 96n22, 96n23, 96n24, 96n25, 97, 97n26, 98-101, 101n46, $102,105,114 \mathrm{n} 78,116,122,124,151$

Bacon, F. 209, 209n77

Badawī, 'A. 45n25, 45n26, 46n27, 50038

Bakker, P.J.J.M. $\quad$ 175n86, 196n15

Balme, D. $63 n 67$

Baltussen, H. 45n25, 196n14
Barbotin, E. $\quad 49 n 36$

Barker, P. $\quad 88 \mathrm{n} 69$

Barnes, J. $\quad 156 \mathrm{n} 47$

Basil of Caesarea 203

Basso, S. 206, 206n6o

Bayle, P. $\quad 195,195 \mathrm{n} 12,210,210 \mathrm{n} 85$

Bazán, B.C. $\quad 45$ n27, 92, 119n91, 161, 161n $59,161 \mathrm{n} 6 \mathrm{o}, 162,162 \mathrm{n} 61,162 \mathrm{n} 62$, $163 n 63,178$

Beck, A.J. $195 \mathrm{n} 13$

Bergeron, M. 42n17, 42n19, 42n2o, 42n21, 43n23, 44n23, 44n24, $49 n 36$

Bernard of Verdun $76,79,79 n 42,84$ 86

Bertolacci, A. 74n23

Bessarion, J. 199, 199n28, 200-204

Boer, S.W. de 150 n29, 196n15

Bonaventure $107 \mathrm{n} 62,151,198,198 \mathrm{n} 22$

Bordt, M. 7on2

Bostocke, R. 205, 206n58, 206n59

Bouwsma, W.J. 201n35

Bouyges, M. 6on58, 63n66, 7on4

Boyle, R. 211, 211n87, 211n88, 211n89

Brenet, J.-B. IX, XIII, 2n2, 37, 37n1, $37 \mathrm{n} 2,38,38 \mathrm{n} 4,38 \mathrm{n} 5,4041 \mathrm{n} 16$, 67n77, 79n45, 8on46, 99n32, 103n49, 119n91, 120, 120n92, 121n97

Bridges, J.H. 174 n82, 174n83

Briggs, C.F. $\quad 134 \mathrm{n} 18$

Brown, S. $\quad 142 n_{5}$

Bruns, I. 42n17, 42n19, 42n2o, 42n21, $43 \mathrm{n} 23,44 \mathrm{n} 23$

Burke, R.B. 174 n82, 174n83

Bérigard, C. 210, $210 n 83$

Calcidius 200, 200n32

Calippus $69,70,77,77 n 35$

Callus, D.A. 107n61

Calma, D. $\quad$ 92, 115n8o, 116n81, 125 
Campanella, T. 206, 206n63, 206n64

Campanini, M. 194 n9

Cano, M. 206, 206n62

Caramello, P. $\quad 103 n 49$

Cardano, G. 195, 207

Carmody, F.J. 71n6, 72n8, 72n12, $101 n 43$

Caston, V. 42n17, 44n24

Cathala, M.-R. $\quad 78 \mathrm{n} 38$

Causabon, I. 208

Cerami, C. viIn2, viII, 32n74, 32n75

Cesalpino, A. 207, 208

Charles, D. 69n1

Charlton, W. 95n19

Chase, M. 7n15, 12n23, 12n24, 21n51

Clagett, M. 149 n26

Clement of Alexandria 203, 203n46

Clement viII (Pope) 208

Cobetto Ghiggia, P. 46n27

Cohen, I.B. 173n81, 211n92, 212n93

Constant, E.A. $196 \mathrm{n} 15$

Conti, A.D. $132 n 12$

Cooper, J.M. $63 n 67$

Copernicus, N. 71

Cos, J. 103n49

Craven Nussbaum, M. $\quad 63 n 67$

Crawford, F.S. 38n6, 145n14

Cremonini, C. 203, 204, 204n5o, 204n51, 204n52, 205, 205n53

Crosby, H.L., Jr. $149 n 26$

Cudworth, R. 209, 209n81

Cyril of Alexandria 203

Dales, R.C. $90 n 7,101 \mathrm{n} 45,103 n 49$, 107n62, 107n63

Davidson, H.A. $1 \mathrm{n} 1,4 \mathrm{n} 6,6 \mathrm{n} 12,21$, 21n $51,21 n_{52}, 21 n_{53}, 25,29 n_{69}, 37 n_{3}$, 61

Davis, E.B. $\quad 211 \mathrm{n} 87$

De Franco, L. $\quad 205$ n57
De Libera, A. 39n8, 39n9, 4on13, $51 n 38,53 n 42$

De Mornay (Du Plessis), Ph. 206, 206n 61

De Raei, J. 194, 194n5

De Silhon, J. 207, 207n69

Dekker, D.-J. $\quad$ 145n15

Delorme, F.M. 91, 152n38

Democritus 65n74, 199, 209

Des Chene, D. $\quad 195 n 13$

Descartes, R. 196, 209, 210

De' Vieri, F. 202, 202n4o, 202n41, $2 \mathrm{O} 2 \mathrm{n} 42,2 \mathrm{O} 3$

Dhanani, A. $153 n 40$

Diels, H. $6 \mathrm{n} 12$

Dionisotti, A.C. $\quad 208 n 73$

Dionysius the Areopagite (Ps.) 203

Donati, S. IX, X, XI, 93n9, 104n57, 105n 58, 115n8o, 121n96, 122n98, 134n18

Donini, P. $\quad 42 \mathrm{n} 17$

Dreyer, M. 119n91, 161n59

Druart, Th.-A. 4on13, 145n14

Du Val, G. 208, 208n75, 209, $209 n 76$

Duba, W. 196n15

Dufour, R. 4,2n17, 42n19, 42n2o, 42n21, 43n23, 44n23, 44n24, 49n36

Duhem, P. $\quad 71 \mathrm{n} 6,76,76 \mathrm{n} 34,77 \mathrm{n} 36$, $79 n_{42}, 83,83 n_{55}, 83 n_{56}, 83 n_{5} 8$, $83 n 59,84$ n6o, 151, 151n 34

Dyke, C. van 134n18

D'Ancona, C. 37n3, 64 n69

Eardley, P. $134 \mathrm{n} 18$

Ebbesen, S. 1 in2

Ellis, R.L. $\quad 209 n 77$

Endress, G. VIIn2, 1n2, 7n15, 38n5, 64n69, 71n6, 72n11, 72n12, 95n21

Epicurus 65n74, 197, 200, 203, 203n 45

Etzkorn, G. $154 \mathrm{n} 41$ 
Euclid 164, 174n83

Eudoxus of Cnidos $69,69 n 1,70$, $77 \mathrm{n} 35,78,78 \mathrm{n} 39$

Eusebius of Caesarea 203

Evans, J. 69n1

Falcon, A. $13 n 30,14 \mathrm{n} 30,14 \mathrm{n} 35,15 \mathrm{n} 36$, 15n37

Fattori, M. 194ng

Fazzo, S. 13n27, 65n71

Federici Vescovini, G. 7n15

Ficino, M. 200, 20on29, 20on30, 201

Filalteo, L. 201, 201n34

Finnegan, J. $\quad 45 \mathrm{n} 26,46 \mathrm{n} 27$

Fonseca, P. da $\quad 207,207 n 67$

Force, J.E. 211n91

Frede, M. 69n1

Freudenthal, G. $\quad 61,61 n_{59}, 64 n 69$

Galen 6o, 197, 197n21

Gannagé, E. 7n15

Gassendi, P. 194, 194n6, 197

Gauthier, R.-A. $\quad 52 \mathrm{n} 41$

Gaye, R.K. $\quad 156 \mathrm{n} 47$

Genequand, Ch. VIIn2, 13n27, 29n67, 33n76, 65n72, 7on4, 73n17, 74n19, $74 \mathrm{n} 22,75 \mathrm{n} 28,198 \mathrm{n} 24$

Gensler, M. 146n16

Geoffrey of Aspall 92, 93n9, 105, 105n58, 106, 106n6o, 107, 107n63, 108, 108n66, 109, 109n67, 109n68, 109n69, 110, 110n7o, 110n71, 125

Geoffroy, M. 37n3, 45n26, 55n44, 57, 57n51, 59n56, 6on $58,63 n 66$

Georges, S. $69 n 1$

Gerard of Cremona 46n27

Geyer, B. $77 \mathrm{n} 35$

Gieben, S. $107 n 63$

Giermek, J. 154n41

Gilbert, F. 196n15
Giles of Rome $134,134 \mathrm{n} 18,151,157$, 158, 158n54, 159, 159n55, 159n56, 16on $57,173,198,198 \mathrm{n} 23$

Gill, M.L. $\quad 90 n_{7}$

Gillispie, C.C. $\quad 71 n 7$

Gilson, E. 198n22

Glanvill, J. 209, 209n79

Glasner, R. VIIn2, VIII, XIII, 1n2, 2, 2n4, 5n9, 13n28, 21n 51, 22, 22n55, 29n69, 31n72, 147, 147n18, 147n19, 147n2o, 148, 148n21, 148n22, 148n23, 148n24, 149-151, 151n31, 151n32, 151n34, 153, 153n39, 154, 154n42, 155, 157n5o, 163, 184, 185n102, 191

Glick, Th. $79 n 42$

Goddu, A. 164, 164n64

Goldstein, B.R. 7on3, 72n 8

Gotthelf, A. $\quad 63 n 67$

Goulet, R. 7n15, 42n18

Grafton, A. 208n73

Graham, D.W. $\quad 95 \mathrm{n} 20$

Grant, E. 76, 76n34, 79n42, 149n26, 175n 85

Green, R. 154n41

Gregory of Rimini $\quad$ XII, XIII, 141-143, 143n1o, 143n11, 143n12, 144, 144n13, 144n14, 145, 146, 161, 163, 164

Gregory XIV (Pope) 202

Grellard, C. 149n27, 150n29, 153n39

Grene, M. 194n5

Guerlac, H. 212n92

Guldentops, G. 59 n56

Gutas, D. 38n5, 45n25

Gál, G. 154n41

Günz, A. 42n18

Haaparanta, L. 146n17

Haase, W. 44n24

Hackett, J.M.G. $\quad 83 n 55$

Hamesse, J. 194n9 
Hankins, J. 2oon29, 20on3o

Hanna, S.A. $7 \mathrm{n} 16$

Hardie, R.P. $\quad 156 \mathrm{n} 47$

Hartmann, P. $79 n 42$

Hasnawi, A. 7n15, 12n23, 13n27, 13n29, 61n59

Hasse, D.N. IX, X, 71n5, 79n45, 196n14

Hayduck, M. 45n25

Heath, D.D. 209n77

Heereboord, A. 194, 194n6

Heiberg, J.L. 14n33, 7on3

Heinsius, D. 208, 208n73

Hetherington, N.S. 7on3

Hipparchus of Nicaea 73

Hissette, R. $118 \mathrm{n} 89$

Hogendijk, J.P. $\quad 71 n 6$

Honnefelder, L. $\quad$ 119n91, 161n59

Hooke, R. 211, 211n9o

Hossfeld, P. $\quad 77 \mathrm{n} 36,101 \mathrm{n} 45,102 \mathrm{n} 47$

Howlett, D.R. $\quad 75 \mathrm{n} 27$

Hubien, H. 171 n79

Hugonnard-Roche, $\mathrm{H} . \quad$ 76n34

Hunt, R.W. 107n61

Hunter, M. 211n87

Hussey, E. $128 \mathrm{n} 4$

Hyman, A. 95n21, 97n27, 98n28, 98n29, 98n3o, 98n31, 99, 99n32, 99n33, 99n34, 99n36, 100, 10on37, 1oon38, 10on39, 10on40, 10on 41

Ibn Bāğğa $\quad \mathrm{X}, 4,12$, 20, 2on5o, 21, 55, $71,171 \mathrm{n} 80$

Ibn Țufayl $\mathrm{x}, 71$

Ibn al-Hayțam $\quad \mathrm{X}, 71,82,82 \mathrm{n}_{52}, 83$, $83 n_{57}, 83 n_{5} 8,85,87$

Iliffe, R. 211n91

Jacob, M.C. $\quad 212 n 92$

Jannone, A. $49 n 36$

Janos, D. 13n27
Javelli, C. $\quad 169 n 76$

Jebb, S. $\quad 173 n 82$

Jedin, H. $\quad$ 196n15

John Blund 106, 107n61

John Buridan 76, 79, 79n43, 79n44, $8 \mathrm{o}, 84,86,171,171 \mathrm{n} 79,175,175 \mathrm{n} 85$, $175 \mathrm{n} 86$

John Dumbleton 160, 164, 175

John Duns Scotus $146,151,160,165$, 165n66, 165n67, 166, 166n68, 166n69, 166n7o, 166n71, 166n72, 167, 167n73, 168, 168n75, 169, 169n76, 189, 190, 191n116

John Philoponus 3n5, 4, 6, 6n12, 7, $7 \mathrm{n} 15,8,10,10 \mathrm{n} 2 \mathrm{O}, 11,12,16,17$, $17 \mathrm{n} 45,18,18 \mathrm{n} 48,19,19 \mathrm{n} 49,2 \mathrm{O}-24$, 29, 45n25, 99

John of Jandun $\mathrm{x}, 69,76,79,80$, 8on 46,8 on 47 , 8on $48,81,81 n_{49}, 82$, 82 n $0,84,85,85 n 63,85 n 64,86,87$, $121,165,167,167 \mathrm{n} 74,168,169$

Jolivet, J. $37 \mathrm{n} 3$

Jones, H. $197 \mathrm{n} 18$

Jones, H.S. $74 \mathrm{n} 2 \mathrm{O}$

Judson, L. $90 n_{7}$

Jung, E. $\quad 87 n 68$

Juste, D. $69 n 1$

Justin Martyr 201, 201n35, 202, 203

Kelley, F. $\quad$ 154n 41

Kennedy, E.S. $\quad 75 n 29$

Knuuttila, S. 1 n2

Koch, J. 198n23

Kosman, A. 9017

Koyré, A. 211, 211n92

Kraye, J. 208n73

Kren, C. 76n34

Kruk, R. 7n15

Kubrin, D. $211 n 92$

Kuhn, H.C. 204n51 
Kupreeva, I. 44n24

Kusukawa, S. 196n16, 197n17

Lagarde, B. $199 \mathrm{n} 26$

Lagerlund, H. 52n41, 8on 46

Lamy, B. 193, 193n2, 193n3, 193n4

Langermann, T. $\quad 82 n 53$

Lay, J. 71n6, 72n10, 73n16, 85n65

Leibniz, G.W. 195, 195n11, 210, $210 n 84$

Leibold, G. 131n11, 154n41, 176n87

Leijenhorst, C. $\quad 196 \mathrm{n} 15$

Lemay, R. 2oon31

Lennon, Th.M. 210082

Lennox, J.G. 63n67, 90n7

Lettinck, P. $4 \mathrm{n} 7,21 \mathrm{n}_{51}$

Leucippus $\quad 65 \mathrm{n} 74$

Liceti, F. $\quad 208,208$ n 74

Liddell, H.G. $\quad 74 \mathrm{n} 20$

Ligorio, P. $\quad 197,197$ n21, 198

Litt, Th. $78 \mathrm{n} 41$

Livesey, S.J. $\quad 165,165 n 65$

Lloyd, G.E.R. $\quad$ 46n27, 69n1, 7on2

Lohr, Ch. 84 n61

Lukács, L. 194n7

López Fajeat, L.X. 38n4

Lüthy, C. 150 n3o

Machiavelli, N. 195

Maggiòlo, P.M. 103n5o

Mahdi, M. 7n16, 18n46, 18n47

Maier, A. 128n3, 132n12, 151, 151n35, $152,152 n_{36}, 157,157 n_{52}$

Maierù, A. ${ }_{103 n} 53$

Malebranche, N. 210, 210n82

Mancha, J.L. $83 n 57$

Mandonnet, P. 107n62, 199n25

Marcolino, V. 143 n1o

Martin, A. VIIn2, 71n4

Martin, C. XIII, 193n1, 197n17

Maróth, M. 13n27
Mazzoni, J. 202, 202n39

McVaugh, M. 150n28

Melanchthon, Ph. XIII, 196

Melsen, A.G.M. van 151

Mendelsohn, E. $\quad 71 n 6$

Mersenne, M. 207, 207n70

Methuen, C. $\quad 197 \mathrm{n} 17$

Michael Scot $51,70,71,71 \mathrm{n} 5,72 \mathrm{n} 8$, $74-76,78,85-87$

Michot, J. $\quad 45 \mathrm{n} 26$

Millás Vallicrosa, J.M. $\quad 82 n_{52}, 83 n 58$

Minio-Paluello, L. $\quad 128 \mathrm{n} 5$

Mohler, L. 199n28

Moraux, P. 44, 44n24, 45n27, 46n27, 46n28, 47n31, 48n33, 5on37

Morgenbesser, S. 211n92

Moses Maimonides X, 21n54, 6on57, 71, 77n35, 153n39, 210

Munk, S. 21n54, 6on57

Murdoch, J.E. $\quad 149,149 n 26,149 n 27$, 15on3o, 152, 152n37, 173n81, 174n84, $175 \mathrm{n} 85$

Nardi, B. $194 \mathrm{n} 8$

Newman, W.R. 150 n30

Newton, I. 211, 211n91, 211n92, 212, 212n93

Nicholas of Autrecourt $153 n 39$

Nicolaus Copernicus, N. 88

Nicole Oresme $\quad 149,163,164,175,176$

Niewöhner, F. $\quad$ 52n41

Nifo, A. $\quad \mathrm{X}, 69,76,79,84,84 n 61$, $84 \mathrm{n} 62,84 \mathrm{n} 63,85,86,86 \mathrm{n} 66,86 \mathrm{n} 67$, 87,88

North, J.D. $\quad 69 n 1$

Olscamp, P.J. $\quad 210 n 82$

Origen 203, 203n 46

Osler, M.J. 197n20

Owen, G.E.L. $\quad 46 n 27$ 
Pacius, G. 208

Panti, C. $107 n 63$

Paravicini Bagliani, A. $103 n 53$

Parker, S. 208, 208n72, 209, 209n78

Pasnau, R. 134n18

Patrizi, F. 202, 202n43, 203, 203n 44 2o3n45, 203n46, 2o3n47, 2o3n48, 204, 204n49, 208

Peter Lombard 146, 160, 199

Peter of Conflans 107

Peurbach, G. 87

Piccolomini, F. 205, 205n55, 205n56

Pickavé, M. 122n98, 196n14

Pius V (Pope) 197

Plato 148, 186n105, 198-200, 202, 203, 209

Plethon, Georgios Gemistos 199n26, 199n27, 200-202

Pluta, O. 52n 41

Podkoński, R. $151 \mathrm{n} 33$

Pomponazzi, P. 84, 195, 200, 20on31, 200n33, 201, 203

Popkin, R.H. $\quad 211 n 91$

Poppi, A. $204 n_{51}$

Pormann, P.E. $\quad 83 n 54$

Possevino, A. 207, 207n65

Postel, G. 201, 201n35, 201n36, 201n37, 201n38, 202

Preus, R.D. 197 n19

Prinz, O. $75 \mathrm{n} 27$

Ptolemy IX, X, 69, 70, 7on3, 71-73, 75, 76,76 n33, 77, 77n $35,79,80,8$ on 47 , $82-86,86 \mathrm{n} 66,87,88$

Puig Montada, J. 1n2, 2, 4n7, 12n23

Puliafito Bleuel, A.L. $\quad 203 n 48$

Quirós Rodríguez, C. $\quad 21$ n54

Ragland, C.P. $\quad 211 \mathrm{n} 86$

Ramon Llull 195
Rashed, M. 1n1, 4, 4n6, 4n8, 7n15, $8 \mathrm{n} 17,12 \mathrm{n} 25,14 \mathrm{n} 3 \mathrm{O}, 15 \mathrm{n} 36,15 \mathrm{n} 38$, 15n39, 15n 4o, 15n41, 16n43, 25n 57 , 25n58, 25n59, 26n6o, 26n61, 27n63, $66 \mathrm{n} 75,67$

Rashed, R. $\quad 76 \mathrm{n} 34$

Raynaud, T. 194, 195, 195n1o

Richard Rufus of Cornwall 154, 154n 43, 155, 155n44, 155n45, 156

Richard Swineshead 176

Richard of Mediavilla $\quad 152,157 \mathrm{n}_{52}$

Richter, V. 131n11, 176n 87

Riedl, J.O. 198n 23

Riondato, E. 204n51

Robert Grosseteste 107n63, 151, $151 n 34$

Robert Kilwardby 107

Robert, A. 149n27, 150n29

Roger Bacon 83, 83n55, 83n58, 84, 87, 91, 93n9, 104, 104n57, 105, 111, 112, $112 n_{74}, 112 \mathrm{n} 75,113,113 \mathrm{n} 76,114,151$, 152, 152n38, 154n43, 157, 157n52, 172, 173, 173n82, 174, 174n82, 175, 184

Roger Swineshead 149

Ross, W.D. 5n9, 128n4

Ruland, H.-J. $\quad 65 n 71,66 n 75$

Sabra, A.I. $\quad \mathrm{X}, 71,71 \mathrm{n} 6,71 \mathrm{n} 7,72 \mathrm{n} 8$, 72n13, 73n15, 73n17, 75n3o, 82n54, $153,153 n 40$

Samsó, J. $71 n 6$

Santos-Noya, M. 143 n1o

Scaliger, J.C. 208

Schmitt, Ch.B. VII, viIn1

Schofield, M. $63 n 67$

Scholten, C. $\quad 7 \mathrm{n} 15$

Schroeder, F.M. 45n27, 46n27

Scott, R. 74n2o

Sebti, M. 45n26

Serra, G. 37n3, $64 n 69$ 
Shank, M. $88 n 69$

Sharples, R.W. $\quad 42 \mathrm{n} 17,44 \mathrm{n} 24,46 \mathrm{n} 27$, 47 n3o, $50 n 37$

Siger of Brabant $\quad 92,115,116,119$, 119n91, 120, 120n94, 121, 121n95, 121n96, 125, 152, 157n52, 163

Simplicius 6n12, 6n13, 7n14, 12, 13n26, 14n33, 14n34, 15, 15n37, 16n44, 18n 48, 19n49, 21, 21n 51

Sirmond, A. 207, 207n68

Sorabji, R. $6 \mathrm{n} 12$

Spedding, J. 209n77

Speer, A. 33n75, 38n5, 93n9, 150n28, 151n33

Spiazzi, R.M. $78 \mathrm{n} 38,102 \mathrm{n} 49$

Steel, C. $\quad 55 n 44,59 n 56$

Steele, R. 91, 152n38

Stephen of Alexandria $\quad 45 \mathrm{n} 25$

Stone, M.W.F. $\quad 45 \mathrm{n} 25,196 \mathrm{n} 14$

Streijger, M. $\quad 175 \mathrm{n} 86$

Stroick, C. 52n 41

Sturlese, L. $\quad 52 \mathrm{n} 41$

Suppes, P.C. $\quad 211 n 92$

Suárez, F. 80, 195

Sylla, E.D. XI, XII, XIII, 69n1, 87n68, 88n69, 141, 141n1, 141n2, 141n3, 142n4, 142n6, 143n1o, 143n11, 144n13, 145n14, 146n16, 149n25, 149n26, 15on28, 16on58, 171n79, 183n98, 189n112

Takahashi, A. VIIIn3

Tannery, P. 196n15

Taton, R. $173 n 81$

Taub, L.C. $70 n 3$

Taurellus, N. 207, 208n71

Taylor, R.C. $\quad 40 n 13,145 \mathrm{n} 14$

Telesio, B. 205, 205n57

Tellkamp, J.A. 38n4

Themistius 40
Theodoretus 203

Theophrastus 38

Thijssen, J.M.M.H. $\quad 175 n 85$

Thillet, P. $\quad 65 n 71,65 n 73,65 n 74,66 n 75$

Thomas Aquinas XI, 52n41, 66n76, 76-78, 78n38, 78n39, 78n4o, 78n41, $86,91,101,102,102 \mathrm{n} 49,103,103 n 49$, 103n5o, 103n52, 103n53, 103n54, 104, 104n55, 104n56, 107n62, 116, 12o, 12on93, 121, 134, 134n18, 151, 159n 57 , 162, 163, 169n 76, 175, 175n86, 176, 199, 199n25, 200, 201, 203, 206-209

Thomas Bradwardine 149, 150, 160, $175,175 \mathrm{n} 85,176$

Thomas Wylton 133, 133n15, 133n16, 134, 134n19, 135

Théry, G. 46n27, 5on38, 52n 41

Todd, R.B. $\quad 45 \mathrm{n} 27,46 \mathrm{n} 27$

Toletus, F. $\quad$ 195, 207, 207n66

Trapezuntius, G. 199, 200

Trapp, A.D. 143n1o

Trifogli, C. XI, XII, 93n9, 105n58, 112n73, 127n1, 128n3, 132n12, 133n15, 134n18, 134n19, 139n28, 139n29, 151n32, 157, 157n53, 158n54, 159, 159n57

Twetten, D. 1n2

Työrinoja, R. 1n2

Ullmann, M. 74n18

Uña Juarez, A. $191 \mathrm{n} 116$

Vallat, Ph. $37 \mathrm{n}_{3}$

Van Riet, S. 96n22, 101n46

Van Steenberghen, F. $120 n 94$

Verbeek, Th. 195n13

Verbeke, G. 45n25

Verger, J. 104n 57

Versteegh, C.H.M. VIIIn3

Voetius, G. 195, 195n13 
Vossius, G.J. $\quad$ 208, 208n72

Vuillemin-Diem, G. $\quad$ 77n37

Walter Burley XI, XII, XIII, 127, 127n2, 128-131, 131n9, 131n1o, 132, 132n12, 133, 133n16, 133n17, 134, 135, 135n20, 135n21, 136, 136n22, 136n23, 137, 138, 138n26, 138n27, 139, 139n28, 141-145, $145 \mathrm{n} 15,146,146 \mathrm{n} 16,147,161,164$, 165,169 n $76,170,170 \operatorname{on}_{7}, 171,171 \mathrm{n} 78$, 172, 18o, 181, 181n96, 182, 182n97, 182n98, 183, 183n98, 183n99, 184, 184n10o, 184n101, 189, 189n114, 19o, 19on115, 19on116, 191, 191n116, 192

Waszink, J.H. 20on32

Webster, J. 209, 209n8o

Wegener, L. 151 n33

Weijers, O. 104n57

Weisheipl, J.A. 9on7, 101n45, 103n49, 103n53, 107n62

White, M.G. $\quad 211 n 92$

Wielockx, R. $115 \mathrm{n} 8 \mathrm{o}$

Wiesner, H. 13n27

William Heytesbury $160,164,175$

William of Auvergne 52n41

William of Clifford 92, 113, 114, $114 \mathrm{n} 79,125$
William of Moerbeke $\quad 77,78$

William of Ockham XII, XIII, 131, 131n1o, 131n11, 132, 132n12, 141, 142, $14.2 \mathrm{n}, 142 \mathrm{n} 6,142 \mathrm{n} 7,143,143 \mathrm{n} 8$, 143n9, 144-147, 153, 154n41, 16o, 161, 163-165, 171, 175, 176, 176n87, 176n88, 177, 177n89, 178, 178n9o, 178n91, 179, 18o, 18on94, 18on95, 181, 184, 187, 187n107, 187n1o8, 188, 188n1o9, 188n11o, 188n111, 189, 189n113, 191, 192

Wirmer, D. 33n75, 38n5, 39n8, 39n9, 4.on $13,55 \mathrm{n} 46$

Wolfson, H.A. $\quad 90 n_{7}$

Wood, R. 119n91, 127n2, 154n41, 154n43, 161n59, 183n98

Woodhouse, C.M. 199n26, 199n27

Xenarchus of Seleucia $3 n_{5}, 13,13 n 30$, 14, 14n3o, 15, 16, 18, 45n25

Yrjönsuuri, M. 146n17

Zimmermann, A. 92

Zonta, M. 57n5o, 57n52, 57n 53, 58n54, $58 \mathrm{n} 55,65 \mathrm{n} 71$ 